\title{
TV or not TV? Subtitling and English skills
}

\author{
Augusto Rupérez Micola \\ Universitat Pompeu Fabra and \\ Barcelona GSE
}

Albert Banal-Estañol

City University and

Universitat Pompeu Fabra

March 5, 2009 


\begin{abstract}
We study the influence of television translation techniques on the quality of the English spoken across the EU and OCDE. We identify a large positive effect for subtitled original version as opposed to dubbed television, which loosely corresponds to between four and twenty years of compulsory English education at school. We also show that the importance of subtitled television is robust to a wide array of specifications. We then find that subtitling and better English skills have an influence on high-tech exports, international student mobility, and other economic and social outcomes.
\end{abstract}




\section{Introduction}

English is the language of the globalised world, and the lingua franca for the international communities in, among others, science, finance, advertising, culture, tourism, law, and technology. As a consequence, it is the most widely learnt foreign language, and is expected to continue growing fast in the coming decades (Graddol, 1997 and 2006). The British Council estimates that about one billion people are currently learning English around the World, 200 million in China alone (British Council, 1997). Sixty-eight percent of the citizens of the European Union (EU) rate English as the most useful foreign language -far from the second position of French with twenty-five per cent (European Commission, 2006).

The prevailing teaching model is to ensure that students gain some basic proficiency in primary school and improve it in secondary school and university, sometimes by using it as a language of instruction for other subjects. ${ }^{1}$ More than 80 per cent of the EU's pupils learn English. The duration of foreign language as a compulsory subject ranges between six and thirteen years in the non-English speaking EU countries (Eurydice, 2005). ${ }^{2}$ In comparison, pupils in England and Wales have foreign language compulsory for five and three years, respectively, and there are no compulsory foreign language requirements in Ireland and Scotland. ${ }^{3}$

Despite the huge amounts of time and money spent, disparities in the quality of English across the Organisation for Economic Cooperation and Development (OECD) countries are very large. In places such as the Netherlands, Denmark and Sweden, about 80 per cent of citizens declare to be able to hold a conversation in English, but the proportion is only about 60 per cent in some of their neighbouring countries such as Belgium, Austria and Finland (European Commission, 2006). Japanese TOEFL exam takers score 192 on average, compared to 218 by their Korean counterparts. The reasons for those disparities do not seem to be straightforward.

In this paper, we suggest that the method used to translate foreign films on television is one of the main drivers of the quality of the English spoken as a foreign language. Subtitled original version programmes provide continuous exposure to foreign languages as spoken by natives, which, we argue, is bound to improve the viewers' vocabulary, grammar, and listening comprehension. Since the US and the UK are the largest producers of fiction programmes, when someone watches a television film in original version, it

\footnotetext{
${ }^{1}$ Japan has just created one hundred "super English high schools" where classes are taught exclusively in that language (Newsweek, 2007).

${ }^{2}$ The minimum is in the region of Flanders in Belgium and the maximum in the Netherlands, Norway, and Luxembourg. Spain is currently introducing additional years for a total of fifteen, starting at the age of three.

${ }^{3}$ In 2004 a British survey discussed by the BBC showed that only one in ten UK workers could speak a foreign language and less than 5\% could count to 20 in a second language (http://news.bbc.co.uk/2/hi/uk_news/3930963.stm).
} 
is likely that the source language will be English. Thus, the citizens of countries where films are shown in original version should be better at speaking English than those where television is dubbed. Interestingly, however, a recent survey of the European Commission (2006) shows that only 12 per cent of Europeans think that watching films in original version is important for their foreign language skills. ${ }^{4}$

In this paper we address three inter-related issues. The first question is "why are there subtitles in some countries and dubbing in others?" We identify and systematically analyse the historical circumstances under which countries opted for one of the alternatives, during the 1930s. We show that dubbing tended to be adopted in countries with dictatorial (and nationalistic) regimes during the period, and those whose national languages were widely used internationally. Smaller countries tended to adopt subtitling, but essentially we find that the "size" of the language, and not the size of the country, determines the adoption of one or the other translation mode.

To our knowledge, no OECD country has moved from dubbing to subtitling since World War II. Schreyogg and Blinn (2008) use path dependence arguments for the case of Germany. ${ }^{5}$ Although the initial conditions were quite similar, "small" differences many years ago (economies of scale, political regime, etc) meant that the film translation industry coordinated in the dubbing solution in some countries while in others it coordinated in subtitling. Citizens adapted accordingly and now have strong preferences for the translation method present in their country (European Commission, 2006). In addition, there are industry and cultural elements that make the transition difficult, including the existence of a consolidated industry and also the, controversial, opinion of many experts who consider dubbing as a superior translation mode (see e.g. Mera, 1998). ${ }^{6}$

\footnotetext{
${ }^{4}$ Europeans think that the best way to learn English is either at school (57 per cent of the interviewed) or through lessons with a teacher, either one-to-one or in groups (40 and 42 per cent, respectively). Other ways in which they think they can learn the language is by visiting the country, either as a tourist or while taking a language course (50 and 44 per cent), or through conversation with native speakers, both through language exchanges and informally (36 and 33 per cent).

${ }^{5}$ See Camerer (2003) for a discussion on the related continental divide games. These are coordination games with more than one Nash equilibria in which, when one starts from the dividing line, two infinitesimally close actions lead to different outcomes because each is attracted to a different Nash equilibrium (i.e. the equilibria operate as "basins of attraction" for the agents' behaviour, who deviate progressively more from the initial situation). In continental divide games people do not always gravitate towards the high payoff equilibrium even when the two outcomes are very different, because the situation reached is extremely sensitive to initial conditions. Although this games are often unsolvable by pure analytical reasoning, social conventions, communication and features of the game display all can have importance in determining the coordinating equilibrium. Moreover, once an equilibrium is reached, changes to the alternative equilibrium are very unlikely.

${ }^{6}$ New digital technology has started to produce a slow convergence process and it is now possible both to watch original version films in traditionally dubbing countries and dubbed versions in countries where subtitling is prevalent. In spite of that, though, we expect the current state of affairs to perdure in the medium term.
} 
The second question is: "what is the influence of the translation mode on the English skills?" Using Ordinary Least Squares (OLS) and treatment regressions, we find that most variables one would a priori have considered, such as the number of years of compulsory English education at school, turn out not to be too important. In our regressions, the quality of the English depends on the linguistic similarity with the local language, the expenditure of education per capita and the quality of the education system. However, the most important explanatory factor is indeed the film translation mode prevalent in each country. We therefore provide empirical evidence that, ceteris paribus, English is better in countries where television is in original version with subtitles. The magnitude of the subtitling effect is very large, corresponding to between four and twenty years of English learning at school, and the interaction effects indicate some complementarity between subtitling and formal learning. Pupils in countries where there are subtitles benefit more from their English classes.

The final research question that we explore is: "How does subtitling influence a country's economic and social outcomes?" We posit that the effects of subtitling for individually acquired English skills might spill over to society as well, accruing at higher aggregation levels and affecting the country's economic, political and social stance in several issues. First, we link the use of subtitles to a country's exports. Our estimates suggest that subtitling increases the ratio of high-tech exports to total exports by 0.5 standard deviations whereas the number of year of compulsory English education is not significant. Second, we find support for the fact that subtitling countries send more students to the US, relative to the total population. We also show that subtitles and English at school are positively related to mergers and acquisitions of US and UK firms, international cross-listing patterns and foreign direct investment from the United States.

Our paper is part of an emerging literature on the effects of television on social phenomena. ${ }^{7}$ In the context of this paper, though, television translation effects are correlated with those of other high Englishspeaking penetration media like music, film or the Internet. We think focusing on television is specially useful due to two reasons. First, it has historically been more widely used than other media. Second, historical circumstances made the television translation mode exogenous to the English quality, which simplifies the methodology. We view our analysis as reflecting the wider influence of English-speaking

\footnotetext{
${ }^{7}$ Television has already been shown to influence social outcomes, including violent crime (Dahl and DellaVigna, 2006), voting turnout (Gentzkow, 2006), democratic/republican patterns (DellaVigna et al, 2007) and international policy (Eisensee and Stromberg, 2007). There is further research on television and social capital in rural comunities (Olken, 2006), antiamericanism (Shapiro and Gentzkow, 2004) and even on the effect of soap operas on women's fertility (Chong et al 2008). Somewhat related to our research, Gentzkow and Shapiro (2007) identify an effect of television on educational test scores. They find a positive effect on verbal skills in the US, which is particularly strong for those children whose mother tongue was not English.
} 
media on language skills, with television as both the most representative media and the one with the cleanest econometric implementation.

The rest of the paper proceeds as follows. In the next section we provide an overview of the current translation modes in the OECD countries and a brief history of dubbing and subtitling. The data is introduced in Section III. In Sections IV, V and VI we present the results related to our main three research questions. In Section VII we conclude.

\section{Television, subtitling and dubbing}

\section{A Foreign film translation in the EU and OECD}

There are three main foreign film translation traditions: dubbing, voice-over and subtitling. Dubbing is the method in which the foreign dialogue is adjusted to the mouth movements of the actors in the film so that the audience feels as if they are listening to actors actually speaking the target language. In voice-over the translation is provided by a single person that does not imitate the action. Finally, subtitling consists of supplying a translation of the spoken source language dialogue into the target language in the form of synchronised captions, usually at the bottom of the screen, while the dialogue is in the original version.

Table 1 provides a list of the translation modes of the countries which are members of the OECD or the European Union and do not have English as their main official language. Twelve countries use dubbing as the preferential translation method and four use voice-over. Fourteen of them use subtitling. Belgium is an interesting case because dubbing is used in the French-speaking Wallonia region but subtitling in the Dutchspeaking Flanders region. The list is suggestive of some patterns. French- (Wallonia, France, Luxembourg, Switzerland) and German-speaking countries (Austria, Germany, Switzerland) all use dubbing. Eastern and, to a lesser extent, South European countries use dubbing or voice-over. In contrast, small language (e.g. Finnish, Dutch, Greek) and Northern European countries mainly subtitle. ${ }^{8}$

\section{$<<$ TABLE 1: FOREIGN TRANSLATION METHOD ACROSS COUNTRIES $>>$}

The pre-eminence of US and UK programmes is essential if the translation mode has to have any influence in the quality of the local English. Table 2 reports the broadcasting time shown in several European countries by country of origin, as a percentage of the total devoted to fiction during January

\footnotetext{
${ }^{8}$ The dubbing / subtitling dichotomy is a simplification. For example, children programmes are dubbed in most countries and some late night less commercial films are sometimes sent in original version in France or Spain.
} 
1997. ${ }^{9,10}$ The importance of US fiction is clear, especially in commercial channels. Among those, US productions accounts for at least 60.7 per cent of the total (France), with a maximum of 79.5 per cent in the Belgian region of Flanders. Though lower, US productions are also important in the public channels. Their percentages range from 19.6 per cent in Germany to 52.9 per cent in France. Prime-time percentages are often above fifty percent. To those numbers one would have to add a significant amount of British productions included in the non-national (other European) epigraph. In contrast, national productions are relatively small, only reaching fifty percent in Germany. In 1995, the EU (including Ireland and the UK) imported US audiovisual products for a total of 6,795 million dollars. For comparison, US imports amounted to 532 million dollars (Ávila, 1997). ${ }^{11,12}$

\section{$<<$ TABLE 2: ORIGIN OF FICTION IN SOME EUROPEAN COUNTRIES $>>$}

\section{B History of subtitling and dubbing}

The film history literature provides a detailed account of the introduction of dubbing and subtitling in cinema. In the times of silent cinema, inter-titles interrupted the course of a film every couple of minutes to provide additional explanations to the audience. It was then easy to replace the original language titles with local text. With the introduction of sound in the early 1920s, the US studios quickly understood that one could not force audiences to watch films in a language they did not understand - as the teaching of English at school was not generalised before the 1960s (Crystal, 2007). ${ }^{13}$

"The language problem was great during the first years of sound film, and this was one of the reasons why in the '20s it took so long before the major production companies turned to

\footnotetext{
${ }^{9}$ Foreign programmes consist mainly of fiction (television series and films) but sometimes also include documentaries (National Geographic, BBC) and other shows. For example, the David Letterman and Oprah Winfrey shows have been popular for years in Scandinavia.

${ }^{10}$ We do not have precise estimates for other countries, but there is ample anecdotal evidence that this is the case also for many of them. For example, television series in Spanish television have been dubbed since its origins in 1957.

${ }^{11}$ Europe is not the only place where this occurs: the U.S. controls about 85 per cent of the world film market and over $80 \%$ of all films given theatrical releases in any part of the world during 2002 were in English (Crystal, 2007).

${ }^{12}$ The importance of English in the film industry is also qualitative. It is not only that today is highly unusual to find a blockbuster film produced in a language different from English but also that, for example, about half the Best Film Awards ever given at the Cannes (France) Film Festival have been to English language productions (Crystal, 2007).

${ }^{13}$ In the 1920s, English language skills in what would become the OECD were poor for two reasons. First, many people did not speak any foreign languages as access to education was very limited and illiteracy high. Second, many of those had access to education learned either French (considered to be the language of diplomacy and widely learned by wealthy classes in Southern Europe) or German (learnt extensively in Northern European due to the region's connections with Germany and the influence of historical figures such as Otto von Bismarck).
} 
sound. Hollywood was simply afraid of losing its leading position in the world market. "Only five per cent of the world's population speak English", D.W. Griffith said in 1923. "Why should I lose ninety-five per cent of my audience?" Film had developed into a universal language which all of a sudden would be shattered into a thousand dialects when sound was added" (cited by Gottlieb, 1997).

Therefore, even if the first ever sound film, The Jazz Singer (1927), was shown with subtitles (Gottlieb, 1997), US film studios quickly started to promote dubbing around the world. As a first step, Paramount Pictures purchased the Des Reservoirs studios in Joinville-le-Pont (outside Paris) in 1929. The new studios were used in the 1930s to dub Paramount films into fourteen European languages, including French and Spanish but also Dutch and Swedish. Tired of having read intrusive inter-titles for many years, people flocked to films in which their own language could be heard.

However, despite the early modest success of subtitling (Gottlieb, 1997), some countries moved on to use this type of captioned translations while others continued dubbing. The film history literature discusses three reasons of why that happened: ${ }^{14}$

First, the literature includes scale economies arguments. In contrast to larger languages, those countries in which small languages are spoken, like the Netherlands, Sweden, Greece or Portugal, seem to have tended to use subtitling as the major translation mode. "The [dubbing] process was difficult, cumbersome, and far too expensive to be worthwhile in a small country" (Gottlieb, 1997). The use of subtitles, was not due to a wish to retain the original soundtrack so audiences could enjoy the actors' voices, nor due the idea that it would be beneficial for people to hear them speak foreign languages. The reason was the limited receipts from box office tickets sales, combined with the low cost of subtitling in comparison with dubbing and a significant number of imported films, which meant that "the production of movies started to require much higher budgets than most of these countries could afford" (Danan, 1991). Note that small countries who shared large languages (e.g. Austria, Switzerland or the French-speaking Wallonia region in Belgium) also adopted dubbing as the preferred translation mode. The determining scale factor would therefore seem to be not the size of the country but the size of its language.

Second, there seem to be political motives related to the emergence of totalitarism. During the 1930s, countries like Germany, Italy, Japan and Spain were taken over by authoritarian regimes with a strong sense of national identity. Dictators often felt that using their language in films would strengthen national pride and therefore seem to have tended to favour dubbing. For example Franco of Spain ruled against any non-dubbed version and, between 1936 and 1975, there were over ninety ministerial guidelines (órdenes)

\footnotetext{
${ }^{14}$ For an excellent overview for the Spanish case, see Ballester Casado (2001).
} 
published to make difficult showing films in a foreign language "because of the evil effects that film release can produce on society" (Szarkowska, 2005). Also the German and Italian governments adopted regulations promoting or even enforcing dubbing. In Italy, where the process of country unification was completed only in 1870, there were still many regions where local dialects were spoken. Mussolini introduced a "Law in Defense of our Language" which ruled that all imported films had to be dubbed into standard Italian, with the idea of using cinema as a means of standardising the language (Szarkowska, 2005). ${ }^{15}$ It is interesting to note that countries which later suffered dictatorships such as Greece did not reverse the subtitling industry standard.

Third, the film history literature proposes an element of cultural identity. Even today, some countries like France or Japan seem to be more concerned about the purity of their culture and they strive to protect it from foreign (mostly US) influence. One way in which cultural identity could be reinforced is by promoting the diffusion of dubbed films. Even today, the Académie Française perceives its role in a similar manner:

"At the end of the 20th century, there is another task awaiting the Académie. The language achieved the fulfillment of its qualities, which made it from two hundred years ago the elite language around the world. The splendour of the French language is today threatened by the expansion of the English, more precisely the American, which has a tendency to invade the spirits, the writings, the media. The development of English is often favoured by the development of new techniques, the accelerated development of sciences, the unprecedented reconciliation allowed by the media and the other communication methods, all factors which push the traditional vocabulary and impose at a high speed the adoption of new words. On August, 4th, 1994, a law relative to the use of the French language (so-called « law Toubon »), which favoured the use of French in the inscriptions, public documents or contracts, public services, congress, media, etc, was voted. "(Source: Official web site of the Académie française, http://www.academie-francaise.fr/role/defense.html $)^{16}$

\footnotetext{
${ }^{15}$ For an exhaustive account of nationalism and dubbing in the Spanish case, see Ballester Casado (2001).

16 "A la fin du XXe siècle, c'est une autre tâche qui attend l'Académie. La langue a atteint la plénitude de ses qualités, qui en ont fait depuis deux siècles le langage des élites du monde entier. Le rayonnement de la langue française est menacé par l'expansion de l'anglais, plus précisément de l'américain, qui tend à envahir les esprits, les écrits, le monde de l'audiovisuel. Le développement de l'anglais est souvent favorisé par l'irruption des nouvelles techniques, le développement accéléré des sciences, le rapprochement inouï que permettent les médias et les autres moyens de communication, tous facteurs qui bousculent le vocabulaire traditionnel et imposent à marche rapide l'adoption de nouveaux mots. Le 4 août 1994 est votée la loi relative à l'emploi de la langue française (dite « loi Toubon »), qui favorise l'emploi du français dans les inscriptions, les documents
} 
According to the historical account, the combination of these three factors would have resulted in the development of national translation industries. This development would have been parallel to the expansion of US cinema around the world and dependent on the technology adopted in each country. ${ }^{17}$ The control exerted by US companies on the film industry continued in the post-war period, mainly because they monopolised the recording equipment, and led to the globalisation of Hollywood-made cinema. American domination of the European market was as its strongest between 1930 and the late 1950s (Danan, 1991). In the 1950s, international markets were flooded with thousands of new films, often backlogged American movies produced during the war and the system consolidated. This is often considered the "golden age" of dubbing in the countries that chose it (e.g. Ávila, 1999).

Upon its introduction in the 1950s, television followed the choice made by commercial cinema in each market (Ávila, 1999). ${ }^{18,19}$ Soon, television required several hours a day of foreign programmes, which had to be translated using either subtitles or dubbing. In particular, the introduction of US "telefilms" and series $^{20}$ became very popular and seems to have created the demand necessary for the growth of national translation industries. This process consolidated the different translation modes in each country (Szarkowska, 2005), an influence that seems to have persisted to our days. For example, some of the main European channels show up to 4,000 hours of translated programmes per year. The same channel might even show dubbed versions in one country and subtitled versions in another (Ávila, 1999). ${ }^{21}$

This prevailing description of events would imply that national audiences have become accustomed to different translation technologies depending on events that occurred in the 1930s (Gottlieb, 1997). If that were the case, the choice would be exogenous to the present quality of the English spoken in the different countries. Dubbing today would be more frequent in large language countries, and those suffering authoritarian or nationalistic governments in the 1930s - 1950s. Their eventual poor English would be a consequence of dubbing, rather than a cause for it.

publics ou contractuels, les services publics, les congrès, les médias, etc." Translation is ours.

${ }^{17}$ In 1931, Germany started to develop its dubbing industry with its own technology, known as Nachsynchronisierung Gerst-Thun, and Hugo Donarelli openned the Fono-Roma studios in Italy. The first Spanish dubbing studios were those of Metro-Goldwyn-Meyer, Trilla-La Riva (both in Barcelona) and Fono España SA (Madrid) in 1933.

${ }^{18}$ The BBC was the initiatior when it broadcasted the German film Der Student von Prag on 14 August, 1938 with English subtitles.

${ }^{19}$ For example, television was introduced in Danmark in 1951 and Spain in 1957.

${ }^{20}$ Including, for example, Perry Mason (television's most successful and longest-running lawyer series of all times), Bonanza or, in the late 60 s and early 70 s Ironside and Little House on the Prairie.

${ }^{21}$ e.g. Canal + present in most European countries. 


\section{The dubbing/subtitling market}

In this context, changing the translation mode would have huge adaptation costs. On the supply side, dubbing countries nationalised and reorganised their respective film industries and created infrastructures that are still central. According to the MCG (2007) report, the subtitling costs are double of the European average in dubbing countries like France, Germany, Spain, and Italy. In contrast, dubbing costs are $66 \%$ more expensive than the European average in Scandinavia and the Netherlands. In total, the turnover of the EU dubbing/subtitling market is estimated to range between 372 and 464 million euros in 2006 . The four major countries in the EU represent $85 \%$ of the market, with the United Kingdom accounting for a significant portion of the work, carried out on request from the American majors as well as European companies. $^{22}$

On the demand side, the use of the native language determines the current preference for one translation technology over the other. According to the latest survey of the European Commission (2006), more than $90 \%$ of the respondents in Sweden, Finland, Norway, Denmark and the Netherlands agree with the sentence "I prefer to watch foreign films and programmes with subtitles, rather than dubbed". Around $30 \%$ of the French, Spanish and Italian and less than the $20 \%$ agree with the same sentence. A recent attempt from the Polish government to change from voice over to subtitling in the public television has received strong opposition, and a recent poll by TNS OBOP found that only $19 \%$ of Poles would welcome subtitled films.

\section{Data}

We use a data panel combining aggregate measures of English skills, historical and contemporary economic and educational variables (the data sources are described in the appendix). Our data set includes the 32 countries that are members of the OECD or the EU and that do not have English as their local language (i.e. we exclude Australia, Canada, Ireland, the UK and the USA). In most of our sample, English is the most widely spoken foreign language. Moreover, in every country covered, except Luxembourg, English is one of the two most widely spoken.

\footnotetext{
${ }^{22}$ Germany's estimates are between 90 and 110 million, France's between 80 and 85 million, Italy's between 55 and 65 million and the United Kingdom's between 90 and 110 million.
} 


\section{A English skills}

Table 3 reports the country list, together with the measurements of the quality of the English spoken in each of them. We use two measurements of the quality of English in each country. ${ }^{23}$ The first consists on EU data on the percentage of people who declare themselves able to hold a conversation in English, as measured in the EU Eurobarometer surveys. This variable, Survey $y_{i, t}$, is a first approximation and has already been used in previous literature (e.g. Fidrmuc and Fidrmuc, 2008). However, in spite of its interest, it has two shortcomings. First, it has been collected only in three occasions for at most 28 countries. Second, the data is self-reported and thus clearly subjective.

\section{$<<$ TABLE 3: ENGLISH PROFICIENCY BY COUNTRY: EU SURVEY AND TOEFL SCORES $>>$}

Therefore, we complement Survey $_{i, t}$ with an alternative measurement. Specifically, we use the yearly averages of the Test of English as a Foreign Language (TOEFL) scores obtained by residents in each country. The TOEFL is a standard English as a foreign language exam accepted by most colleges and universities in the world. It is based on multiple-choice and it is intended to measure the ability to communicate in English at a high level. Its standardisation means that it is relatively fair and accurate: the fact that everybody takes a similar test eliminates the inconsistency of interviews and other softer methods. This TOEF $L_{i, t}$ variable, thus, addresses the missing data and subjectivity concerns with the variable $S u r v e y_{i, t}$ and allows us to increase the sample size by adding non-EU OCDE countries.

One potential problem with TOEF $L_{i, t}$ is that it might suffer from self-selection issues. It is likely that TOEFL takers will be those who are interested in pursuing studies abroad. Hence TOEFL might not measure the quality of the English spoken by the whole population but a sub-sample of those with sufficient educational attainment or income to study overseas. TOEFL takers are likely to be better at speaking English than the country average.

The issue is whether the different national sub-samples are biased to different degrees, i.e. whether some are more representative than others. We think it is plausible that there might be a correlation between income inequality and the dispersion in the English spoken such that the bias introduced by the TOEFL would grow with income inequality. In egalitarian countries, most people will have achieved a similar level of foreign language skills, just as they tend to have similar levels in math or science. In contrast, in countries with less egalitarian income distribution, the wealthy could speak foreign languages better than poor people, would be more likely to study abroad and thus present a higher proportion of test takers. To

\footnotetext{
${ }^{23}$ Ideally, one would like to work with individual-level data to account for personal variables that are likely to influence English level such as education, income, etc. Unfortunately, we are not aware of any dataset with these characteristics.
} 
address this potential problem, we will report regressions on both the original TOEFL scores and on an income distribution adjusted version:

$$
\text { TOEFL } L_{i, t}^{A}=T O E F L_{i, t} \cdot\left(1-G_{i}\right)
$$

TOEF $L_{i, t}^{A}$ is the adjusted TOEFL and $G_{i}$ is the Gini coefficient for country $i$. A low $G_{i}$ indicates more equal wealth distribution, and a high Gini coefficient indicates more unequal distribution. In the extreme cases, 0 would correspond to perfect equality, when everyone had exactly the same income and $T O E F L_{i, t}$ was perfectly representative of the English skills of the whole population. 1 would correspond to perfect inequality, where one person had all the income and took the TOEFL, while everyone else had zero income and did not speak English. In our dataset, the $G_{i}$ ranges between 0.22 for Slovenia and 0.46 for Mexico.

None of our measures of English quality is perfect. However, to our knowledge these are the best measurements available. In addition, each of them is imperfect due to different reasons so that, they might complement each other and, together, provide a good sense of the quality of the English spoken in different countries. We feel that we strenghten our arguments by showing that our results appear in both specifications and, as a result, we show all our main regressions for Survey $_{i, t}$ and $T O E F L_{i, t}^{A}$.

\section{B Economic and educational variables}

Our main explanatory variable is a dichotomous variable taking the value of zero if foreign television programmes are mainly showed dubbed or with voice-over in a given country and one if they are mainly subtitled. ${ }^{24}$ We give a value of one to Belgium because the population in the subtitling region (Flanders) is larger than in the dubbing region (Wallonia). Similarly, we give a value of one to Estonia because most foreign programmes are subtitled.

As an attempt to measure the actual exposure to subtitled original version programming, we have collected information on television penetration and also on television and cinema audiences. The CIA world factbook provides estimates of the number of televisions per 10,000 inhabitants in each country. A report for the EU of Media Consulting Group provides information on the average number of hours of television watched in a year, the number of homes with television and the average annual cinema attendance per person, and the percentage of cinema films only shown with subtitles.

The remaining variables are presented in Table 4. We use Dyen et al. (1992)'s lexicostatistical index of language similarity between English and the local language. The index is the percentage of words in

\footnotetext{
${ }^{24}$ Most countries offer a mixed system with strong predominance of one translation mode. For example, it is possible to watch original version films shown at late night in French channels and children programmes are often dubbed in Sweden.
} 
a given list that are common/similar between two languages and we re-scale it between 0 and 1,000. For example, the similarity index between English and Dutch is 608, with German is 578, and with Spanish 240. We assign a value of 0 to non-Indoeuropean languages because they are not in the index and their characteristics are very distant from those of English. ${ }^{25}$

\section{$<<$ TABLE 4: EXPLANATORY VARIABLES --DESCRIPTIVE TABLE $>>$}

Since English is mostly taught at school, educational variables are likely to play an important role. We use first the number of years of English education at school, which is mainly taken from the European Union website. We also use lagged and contemporary data on the age at which pupils started learning foreign languages, teaching intensity (years and minimum hours learning foreign languages), as well as the percentage of them who learn English and how many additional languages they learn. The data is taken from Eurydice (2005). Finally, we use the overall national Programme for International Student Assessment (PISA) score to measure the quality of the educational systems.

English quality might also depend on the public investment in education. We obtained pupil/teacher ratios and public education expenditure data for each country from the IMD's World Competitiveness Yearbook (WCY) database. This database also provides us with economic, social and geographical indicators such as gross domestic product (GDP), population, the employment in services as a percentage of the total, tourist receipts, remunerations, internet usage, high-tech exports and R\&D personnel per capita.

One of our research questions relates to the causes of the introduction of subtitling in the different countries. Hence, we use a number of historical variables, including GDP, population, GDP per capita. We use 1933 - the year in which Adolf Hitler became Germany's Chancellor - as the measurement date. Finally, we classify each country as a dictatorship or democracy in 1933 using the standard definitions in the Polity IV dataset, and also use the raw index (Democracy index) bounded between -10 and $+10 .{ }^{26}$

\section{Descriptive Statistics}

Table 5 provides descriptive statistics of economic and educational variables. Subtitling countries do not differ significantly from dubbing ones in wealth per capita. Interestingly, although they spend significantly more in education ( $\$ 512$ per capita) and obtain better PISA scores (8 points), they do not differ in the

\footnotetext{
${ }^{25}$ Non-indoeuropean languages in our dataset are Finnish, Hungarian, Korean and Japanese. Our results are robust to excluding them from the analysis.

${ }^{26}$ Polity IV is the most widely used data resource for studying regime change and the effects of regime authority. It carries data through 2007 and is currently under the direction of Monty G. Marshall at the Center for Systemic Peace and George Mason University. (www.systemicpeace.org)
} 
number of years of formal English education. Yet, there are striking differences in their English-speaking skills. Subtitling countries score 77 points higher in the TOEFL, and obtain 23 points more in the EU Survey of English proficiency.

$$
<<\text { TABLE 5: DESCRIPTIVE STATISTICS }>>
$$

\section{The determinants of the translation mode}

In this section we empirically examine the historical account of the spoken-films introduction in the 1930's. Table 6 reports probit regressions for the decision to use dubbing or subtitling in the early days of sound cinema. The default value is dubbing, so positive parameter estimates indicate that the variable is more conducive to subtitling and negative estimates suggest dubbing propensity. Since this is a cross-section, we only have one observation per country. Therefore, with the exception of the last three models, we use one single explanatory variable in each regression. In the last three models, we combine the explanatory variables with individually significant effects.

\section{$<<$ TABLE 6: HISTORICAL CAUSES OF DUBBING AND SUBTITLING $>>$}

The language size estimates are consistently negative and significant (Models I, IX, X and XI). This suggests that countries with larger languages tended to adopt dubbing, while countries with smaller languages adopted subtitling. Although the size of the economy has also a negative and significant effect in isolation, it loses its significance when combined with the size of the language (Models II and IX). This suggests that it is the size of the language rather than the size of the economy that helps explaining the decision to dub or subtitle. The coefficients trade openness and material well-being (GDP per capita) are positive but not significant (Models III and IV).

We also find support for less democracy being conducive to dubbing, both with the Dictatorship indicator, or the raw Democracy index values (Models V and VI). The democracy index, though, is only significant at a ten percent level and loses its significance when combined with the dictatorship variable (Model IX). Finally, geographically more distant and linguistically closer countries favour dubbing but the coefficients are not significant (Models VII and VIII).

In the last model we report our preferred specification (pseudo-R square of $48 \%$ ), where dubbing is explained by the size of the national language and the dictatorship dummy. We use this specification as first stage to instrument English skills in the following sections. 


\section{The determinants of English proficiency}

\section{A Main results}

Table 7 reports regressions on educational factors that could plausibly influence the quality of the English spoken in a country. The dependent variable is Survey $_{i, t}$. The first four columns include different variations of OLS models. The fifth to eighth columns report the estimation of a Treatment Effects Regression (Heckman, 1979), controlling for a possible endogeneity of the Subtitles indicator. ${ }^{27}$ We argue that the political conditions of the country in 1933 as well as the size of the local language are exogenous variables to explain current English skills. In any case, the Inverse Mills Ratio in the second step regression is a test of the endogeneity of the treatment variable and its correction. ${ }^{28}$ We do not report the first-step probit regression because it is similar to the last model in Table 6. In this table, as in the next ones, we report the standard deviation of the endogenous variable used to compute economic significance levels.

The subtitles indicator is positive and significant in all specifications, irrespective of whether it instrumented or not. The effect is very large - equivalent to about twenty years of English teaching on average in OLS regressions, and to about forty years under treatment effects. In economic terms, subtitling increases the EU Survey results by 0.78 standard deviations on average. For comparison, a country would need to increase its expenditure in education per capita by $\$ 1849$ (the average expenditure in education per capita is $\$ 926$ ), or equivalently 200 percent to achieve the same English skill levels. Given that the total population of our dubbing countries is 315 million, the annual cost of dubbing in the OECD is approximately $\$ 582$ billion of annual education expenditure. For countries like Spain, it is about $\$ 81$ billion annually, approximately 54 per cent of the State budget. When we instrument the subtitles indicator, the magnitude of its coefficient increases even further.

There are other less important determinants of English quality. The similarity of the local language and English is highly significant in all the regressions. The survey results increase by 0.47 standard deviations on average when increasing the similarity coefficient by one standard deviation. The number of English

\footnotetext{
${ }^{27}$ Heckman (1979) formulates a selection model where the treatment variable ("Subtitles (Y/N)" in our case) is instrumented in a first step. The initial probit also allows to compute the Inverse Mills Ratio, which is used as a regressor in the second step together with the instrumented treatment variable. Heckman (1979) shows that the two-step procedure is consistent, although the full model can also be estimated with maximum likelihood. We use the two-step estimator because it allows us to report R-squared coefficients, and therefore to compare its explanatory power with OLS estimates.

${ }^{28}$ In Treatment Effect Regressions, the coefficient on the Mills ratio measures the effect which is due to intrinsic country differences (self-selection), as well as the effect that is due to the pure direct procedural difference itself. The sign of the coefficient is however meaningless.
} 
education years at school is marginally significant in only one regression. When significant, one additional year increases English skills by 0.06 standard deviations. Moving from the country with the fewest years of English education (seven) to the most (eleven) increases English skills by 0.24 standard deviations. The quality of the education system (PISA assessment) is significant in all the regressions. A one-standard deviation increase in the PISA score (= 30.12 points) increases English skills by 0.34 standard deviations. The pupil-to-teacher ratio is however insignificant, possibly because its effect is subsumed in the expenditure in education or the PISA score variables.

\section{$<<$ TABLE 7: FACTORS INFLUENCING ENGLISH QUALITY, with EU Survey $>>$}

Table 8 reports regressions with $T O E F L_{i}$ and $T O E F L_{i}^{A}$ as dependent variables. The results are similar. Subtitling increases unadjusted and adjusted TOEFL scores by 0.06 and 0.03 standard deviations, which is equivalent to 3.4 and 0.75 years of English education. The first three columns include different variations of OLS models. The quality of the educational system is clearly significant only when using the adjusted scores. The economic significance of the expenditure in public education per capita is even

lower than in Table 7. The magnitude of its coefficient at least multiplies two-fold once it is necessary to instrument for the subtitles indicator. In these regressions the Inverse Mills Ratio is only significant in the first model.

$<<$ TABLE 8: FACTORS INFLUENCING ENGLISH QUALITY, with non-adjusted and adjusted TOEFL $>>$

Together, Tables 7 and 8 provide evidence of a significative and very large effect of subtitling on the quality of the English. The effect is equivalent to at least twenty years spend learning the language at school when English skill is measured with Survey $_{i, t}$, more than three when it is measured with TOEF $L_{i}$ and a bit less than one if it is measured with $T O E F L_{i}^{A}$. As one would expect, the expenditure in education and class sizes are also positively related to English quality, although the coefficients are not always significant.

Table 9 provides further evidence from another data set. Bonnet (2002) reports English evaluations in eight European countries evaluations, but disaggregated in four different types of skills: listening comprehension, written production, reading comprehension and linguistic competence (i.e. grammar). Subtitling countries perform better than dubbing countries across skills. However, there is wide variation in the differences. Pupils in subtitling countries score almost twice as high in the listening comprehension test (66.29 vs. 34.65$)$ but only about $18 \%$ higher in linguistic competence (63.42 vs. 53.38). The differences in writing and reading comprehension are somewhere intermediate. We interpret this evidence as consistent with our regression findings. One would expect that original version television improves a lot the skills one 
gains by listening frequently to English speakers (e.g. listening comprehension), but not as much the skills requiring formal school training (e.g. grammar).

\section{$<<$ TABLE 9: DISAGGREGATING BY TYPE of ENGLISH SKILLS Source: Bonnet (2002) >>}

\section{B Subtitles as a complement to formal education}

Recall that dubbing and subtitling countries do not statistically differ in terms of years of formal education (see Table 5). In dubbing countries there are on average 9.7 years of formal English education; in subtitling countries there are 10. In this section, we are interested in computing "the value of one year of English education" in subtitling vs. dubbing countries. Hence, we interact the subtitles indicator with the number of years of formal English education variable. Table 10 provides estimates of the full model using the two dependent variables in OLS and Treatment Effect regressions.

\section{$<<$ TABLE 10: INTERACTION BETWEEN FORMAL EDUCATION AND SUBTITLES $>>$}

In the EU survey regressions, the subtitles dummy has a negative and significant coefficient (-56.7) and the interacted dummy a significant and positive coefficient (7.2). This means that a subtitling country with 8 or less years of formal education in English would score less than a dubbing country. However, the productivity of an additional year above eight is equivalent to 7.2 points in the endogenous variable. Although the results are similar, it is not necessary to instrument the subtitle dummy because the Inverse Mills ratio is not significant.

In the Adjusted TOEFL results, the subtitles dummy has a positive and significant coefficient (19.43) and the interacted dummy a marginally significant and negative coefficient (-1.43). This means that a subtitling country with thirteen or less years of formal education in English would score more than a dubbing country. ${ }^{29}$

In subtitling countries, the value of one year of English education results in five EU survey points (7.2 - 2.2) and 4.12 points (5.55-1.43) in the Adjusted TOEFL score. In contrast, in dubbing countries, one year of English does not significantly affect their EU survey results, but increases the adjusted TOEFL score by 5.5 points. Overall, the regressions suggest that subtitles increase more the marginal productivity of one additional year of English at school.

\footnotetext{
${ }^{29}$ A dubbing country with $Y$ years of English education obtains an adjusted TOEFL score of $5.55 \times Y$. A subtitling country with $Y$ years of English education obtains an adjusted TOEFL score of $19.43+(5.5-1.43) \times Y$. At $Y=13.12$ both scores are equal.
} 


\section{The effect of television penetration and viewing}

In Panel 1 of Table 11, we report regressions with an additional interaction between television penetration and subtitling. English skills are positively related to television penetration. An increase of 10 television sets per 1,000 inhabitants results in an increase in the EU Survey score of 0.02 standard deviations on average, and an increase in the adjusted TOEFL score of 0.01 standard deviations. The coefficient is positive but not significant once we instrument the interaction between penetration and subtitling (Model 5). The coefficients for the remaining explanatory variables are similar to those in Tables 7 and 8 .

\section{$<<$ TABLE 11: ENGLISH QUALITY AND television PENETRATION AND VIEWING $>>$}

In Panel 2, we show the results with an interaction between television viewing and subtitling. Surprisingly, in subtitling countries, higher viewing levels seem to be negatively associated with English skills. The interaction coefficient is negative and significant in all the regressions, both when using the EU scores and the TOEFL results. The difference between the two panels can be explained by the correlation between the television penetration and viewing variables, which is significantly negative (-0.3). In addition, many observations are dropped in the regressions of the second panel (including all non-EU), because we have less data on viewing than on penetration.

\section{Additional robustness checks}

In Table 12 we control for additional measures of financial and economic development, and alternative determinants of the translation method. The sign of the Subtitles indicator is robust to the inclusion of the additional variables, even after controlling for endogeneity. The coefficient is insignificant in the case of the adjusted TOEFL but becomes significant once controlling for endogeneity. The years of English education lose explanatory power with respect to Tables 7 and 8.

\section{$<<$ TABLE 12: ADDITIONAL CONTROLS $>>$}

Richer countries speak better English, as GDP per capita is correlated with education expenditures (correlation coefficient is 0.63 , significant at the one-percent level). The effect, however, is only significant in one of four regressions. Larger countries obtain worse English results, especially TOEFL scores. Trade to GDP and the percentage of exports that are high tech are also positively related to TOEFL scores, although the direction of the causality deserves further investigation. The percentage of people employed in the services sector affects positively the EU survey results but negatively the TOEFL scores. Countries that are more dependent on touristic activities speak worse English. 
As a second robustness check, we use cinema rather than television subtitling variables. Specifically, Table 13 shows regressions of the English skills on the percentage of films subtitled and on the average number of subtitled films watched (i.e. the interaction of the percentage of movies subtitled and the average cinema attendance per person). In the case of the EU survey results, both variables are highly significant, the first with a negative sign and the second with a positive one. At the mean average attendance (1.5 movies per year), the effect is highly positive $\left(23.5=-8+1.5^{*} 21\right.$ units in model 1$)$. In the case of the TOEFL results, the interaction term is sometimes negative (models 2 and 4). However, even at the maximum level of attendance ( 3 movies per year), the effect is highly positive $\left(8=26-6 * 3\right.$ in model 2 and $10=25-3^{*} 5$ in model 4). The bottom line is that subtitling has a positive impact on a country's English skills.

$<<$ TABLE 13: SUBTITLING IN CINEMAS $>>$

\section{English, economic and social outcomes}

The economics literature explores some implications of speaking English well. A large part has focused on immigrant populations in the US and concluded that better English conduces to higher earnings (Bleakley and Chin, 2004 and 2007; McManus 1985; McManus, Gould and Welch 1983). Levinshon (2004) finds similar results with racial groups in South Africa.

However, there is not much literature on the country returns of having a population with good English as a foreign language skills. The issue probably deserves several papers. In this section, we only intend to sketch some of the possible implications, rather than providing a full-fledged econometric analysis. Table 14 summarises the empirical results.

\section{$<<$ TABLE 14: ENGLISH, ECONOMIC and SOCIAL OUTCOMES $>>$}

High-tech exports Most top scientific journals are published in English so that, nowadays, it is almost impossible to become a scientist without a significant knowledge of the language. In addition, English is the language of international commerce. It is even the working language in many multinationals based in non-English speaking countries (e.g. Arcelor Mittal (India), Cemex (Mexico), Nestlé (Switzeland) and Nokia (Finland)). Hence, it seems plausible that the countries in which people speak better English will have an edge against international competitors, specially in high-tech industries.

In the regressions we link the use of subtitles, years of English and quality of the education system to a country's technology exports. The models suggest that subtitling increases the ratio of high-tech exports 
to total exports by 0.5 standard deviations, whereas the number of years of English education do not affect significantly the level of high-tech exports.

Student mobility Television might be conducive to cultural affinity and one of the ways in which this might express itself is in a preference towards receiving education in English-speaking countries. One could conjecture that knowing more English might tend to make studies in the US both easier and more attractive. In our regressions, subtitling countries seem to be more likely to send their students to the US (the economic effect is 0.01 standard deviations). Larger but poorer countries are also relatively more likely to export students to the US.

Cross-border mergers Several papers have shown that a common language is significant at determining the target-acquiror match. They typically use a gravity model which explains the choice of a target firm with variables such as geographical distance, common border, and common language. The latter variable systematically turns significant (see Coeurdacier et al., 2008, and the references therein).

Along the same lines, we test whether the use of subtitles is correlated with the merger activity between English- and non-English speaking areas. As the table shows, subtitling yields ten additional acquisitions of US/UK firms per year or around twenty standard deviations.

Cross-listings Pagano et al. (2002) find that a common language is a strong determinant of the decision of where to list. For instance, the Vienna Stock Exchange is the largest natural destination for German companies. Most of the foreign firms listed in the US come from the UK This clustering would indicate that companies tend to cross-list in countries culturally close to their country of incorporation.

In this context, knowing more English might tend to make the country closer to Anglo-Saxon values. We argue that, as countries improve their English-speaking abilities, their firms will be more likely to list in the US, with all the financial advantages that a dual-listing brings about. The table shows that subtitling yields an additional 2.6 additional cross-listings per year.

Cross-border trade and equity flows The international trade literature has shown that a common language is a factor that determines cross-border trade (Frankel and Rose, 2002). A related effect comes from findings by Portes and Rey (1999) and Tesar and Werner (1995), who show that geographical proximity and cultural homogeneity (especially common language) increase cross-border equity flows. Grinblatt and Keloharju (2001) find that investors tend to hold stocks whose corporate language is their own. 
In the context of our research, one would expect that trade and equity flows with the US will be larger in those countries who speak better English. Again, subtitling countries seem to be more likely to receive foreign direct investment (FDI) from the US, although the economic effect is of only 0.45 standard deviations.

\section{Conclusions}

The general message in this paper is simple. Subtitled original version fiction provides continuous exposure to foreign languages. The US is by far the largest producer of fiction programmes shown around the world, so when someone watches a television film in original version, it is very likely that the language source will be English. Subtitled television programmes then improve the English skills of the viewers, and, thus, the citizens of countries where films are shown in original version speak better English than those where television is dubbed.

We show that dubbing and subtitling countries do not differ significantly in wealth per capita or length of formal English education. Yet there are striking differences in their English skills. Subtitling countries score 77 points higher in the TOEFL, and obtain 23 points more in the EU Survey of English proficiency. We show in panel regressions that the differences in English skill can be significantly explained by the film translation method used in the country. We identify an effect equivalent to between four and twenty years of English education at school. Our results are robust to the inclusion of other determinants of English skill, like wealth or economic development.

These findings are robust to the use of historical instruments for the subtitles variable. We use discrete choice models to analyse the reasons why some countries use subtitling and others dubbing, and find that large countries and those with a dictatorship in the 1930s were more prone to adopt subtitling than smaller, democratic countries. Our analysis finds support for the film history account. To our knowledge, this is the first econometric analysis of those findings.

In economic terms, the subtitles effect is sizeable. A country that uses dubbing would need to increase its expenditure in education per capita by 200 per cent to achieve the same English skill levels as in a subtitling country. Adding up the total population of dubbing OECD countries (315 million), the annual cost of dubbing is approximately $\$ 582$ billion per year.

Subtitling, via an increased ability in English language skills, has a positive impact along all sorts of economic and social dimensions. The paper also sketches some evidence on a number of these effects. Subtitling increases the ratio of high-tech to total exports, the number of takeovers by UK or US firms, 
the cross-listings of domestic firms in the US, and the US foreign direct investment. We have also shown that it might facilitate student mobility.

We believe that our findings can have profound in countries with little but growing exposure to Englishspeaking media. Take the case of China. According to a recent report by consultants McKinsey, fewer than 10 per cent of Chinese university graduates are suitable for international positions mainly because most do not speak English (Financial Times, 2005). The welfare and integration with Western societies impact could be huge if China increased the use of subtitling.

This paper is a first attempt to measure the impact of subtitling on the quality of English spoken but there is still a lot of ground to cover. For instance, we have taken an aggregated national view. Some analyses (e.g. European Commission, 2005), though, find significant differences of language skills between men and women (52 per cent to 47 per cent), the young and the old (69 per cent versus 35 per cent), city and countryside people (55 per cent and 47 per cent) and across levels of education (20 per cent of those that finished their studies at the age of 15 are conversational in a foreign language, compared to 79 per cent of those who are still studying). Econometric studies at the micro-level should probably shed light on those findings.

Our paper contributes to the emerging literature on the effects of television on social phenomena. In our context, though, it is likely that television translation effects are correlated with those of other media like music, film or the Internet. We think our focus on television is useful due to two reasons. It is the dominant media. and historical circumstances mean that the television translation mode and English quality are were exogenously determined. However, our analysis should be viewed as reflecting the wider influence of English-speaking media on language skills, with television as both the one which is most representative and which has the cleanest econometric implementation.

\section{Appendix: data sources}

English skills: The data is published as tables in three Eurobarometers (European Commission, 2001, 2005 and 2006). The reports are freely downloadable from the EU website (http://ec.europa.eu/). The surveys are quite large. The 2005 issue was fielded in all $25 \mathrm{EU}$ member states, plus accession (Bulgaria and Romania), candidate countries (Croatia and Turkey), and the Turkish Cypriot Community with a total of 29,328 interviews to people aged 15 years and over. Half of the citizens of the Member States claim to be able to speak at least one foreign language at a conversational level. The question asked in the survey is: "Which languages do you speak well enough in order to be able to have a conversation, excluding your 
mother tongue?"

TOEFL: The data is freely downloadable from the exam administrator's website (http://www.ets.org).

Dubbing / Subtitling: We have obtained the information through Wikipedia and complemented it with information from people resident in some of the countries.

Historical data: For measurements of GDP, population and GDP per capita, we use the Maddison dataset (http://www.ggdc.net/maddison/). For trade openness, we use the data compiled by Barbieri (2005) (http://people.cas.sc.edu/barbierk/databases.html). For the dictatorship and democracy indices, we use the Polity IV dataset (http://www.systemicpeace.org/polity/polity4.htm).

PISA: The data is downloaded from the Programme for International Student Assessment (PISA) website (http://www.pisa.oecd.org).

Language similarity index: Data obtained from Dyen et al. (1992).

Education data: Data on the age at which pupils started learning foreign languages, teaching intensity (years and minimum hours learning foreign languages), as well as the percentage of them who learn English and how many additional languages they learn is taken from Eurydice (2005).

World Competitiveness Yearbook: The data can be purchased from IMD's website (http://www.imd.ch/re WCY analyses the ability of countries to create and maintain their competitive advantage. It provides 312 ranking criteria for 53 countries. The data in the WCY are drawn from standard secondary sources and an annual opinion survey sent to over 4,000 executives around the globe. It includes information about economic performance (77 criteria, e.g. employment, price levels, currency stability), government efficiency (72 criteria, e.g. institutional framework, business legislation), business efficiency (68 criteria, e.g. productivity, management practices) and infrastructure (basic, technological, scientific...). Our data encompasses the 1997-2007 period.

television and cinema variables: The average number of hours of television watched in a year, the number of homes with television, the average annual cinema attendance per person and the percentage of films which are only shown subtitled in the cinemas are from a report for the EU of Media Consulting Group, which is available at http://ec.europa.eu/information_society/media/overview/evaluation/studies/index_en.htm.

Other variables: We calculate distances between national capitals and relevant English-speaking cities as follows: For European countries, the reference is London. For Mexico, it is Los Angeles. For Japan and South Korea, the average between the distance to London and Los Angeles. In all cases, we use the distances appearing in the Geobytes website (http://www.geobytes.com/citydistancetool.htm). International student mobility data was obtained through the Opendoors' Report of International Educational Exchange (http://opendoors.iienetwork.org). The "affinity of nations" data was compiled by Erik Gartzke 
and downloaded from his website (http://dss.ucsd.edu/ ${ }^{\sim}$ egartzke/).

\section{References}

[1] Acemoglu, d. and Joshua Angrist (2001): "Consequences of employment protection? The case of the Americans with Disabilities Act". Journal of Political Economy, pp. 915-957.

[2] Ávila, A. (1997a): La historia del doblaje cinematográfico. Cims editores. ISBN 84-89643-37-3.

[3] Ávila, A. (1997b): El doblaje. Catedra. ISBN 84-376-1521-6.

[4] Ávila, A. (1999): Asi se crean doblajes para cine y televisión. Cims editores. ISBN 84-8411-518-6.

[5] Ballester Casado, A. (2003): Traducción y nacionalismo: la recepción del cine americano en España a través del doblaje (1928-1948). ISBN 84-8444-230-6.

[6] Barbieri, K. (2005): The Liberal Illusion: Does Trade Promote Peace? Ann Arbor: University of Michigan Press.

[7] Bleakley, H., and Chin, A. (2004), "Language skills and earnings: evidence from childhood immigrants", Review of Economics and Statistics 86, 481-496

[8] Bleakley, H., and Chin, A. (2008), "What Holds Back the Second Generation? The Intergenerational Transmission of Language Human Capital Among Immigrants", Journal of Human Resources, forthcoming.

[9] Bonnet, G. (ed) (2002): The assessment of pupils' skills in English in eight European countries: A European project. Report downloadable from cisad.adc.education.fr/reva/pdf/assessmentofenglish.pdf

[10] Carliner, G. (1981): "Wage differences by language group and the market for language skills in Canada". Journal of Human Resources, XVI, no. 3.

[11] Chaume, F. (2003): Doblatge i subtitulació per a la television. ISBN84-9766-027-7.

[12] Chong, A., Suzanne Duryea , Eliana La Ferrara (2008): Soap operas and fertility in Brazil. CEPR working paper. http://www.cepr.org/pubs/new-dps/dplist.asp?dpno=6785

[13] Coeurdacier, N., R.A. De Santis, and A. Aviat (2008), "Cross-border mergers and acquisitions: financial and institutional forces", working paper.

[14] Crystal, D. (1997): English as a global language. Cambridge University Press, ISBN 978-0-521-53032-3. 
[15] Dahl, Gordon and Stefano DellaVigna (2006), "Does movie violence increase violent crime?" NBER working paper. http://www.nber.org/papers/w13718

[16] Danan, M. (1991): "Dubbing as an expression of nationalism". Meta, vol. 36, no. 4, pp. 606-614.

[17] De Bens and de Smaele (2001): "The inflow of American television fiction on European broadcasting channels revisited". European Journal of Communication, vol. 16, no. 1, pp. 51-76.

[18] DellaVigna, Stefano and Ethan Kaplan (2007): "The Fox News effect: media bias and voting". Quarterly Journal of Economics, Vol. 122, pp. 1187-1234. Available from http://elsa.berkeley.edu/ sdellavi/wp/foxvote06-08-18.pdf

[19] Diaz-Cintas, J. (2001): La traducción audiovisual: el subtitulado. Ed Salamanca Almar.

[20] Dyen, I., Joseph B. Kruskal and Paul Black (1992): An Indoeuropean Classification: A Lexicostatistical Experiment. Transactions of the American Philosophical Society, vol. 82, part 5.

[21] Eisensee, Thomas and David Stromberg (2007), "News Floods, News Droughts, and US Disaster Relief", Quarterly Journal of Economics. Available from

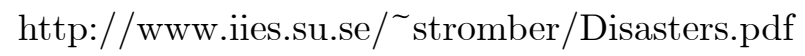

[22] Eurydice (2005): Key data on teaching languages at school in Europe. ISBN 1830-2076.

[23] European Commission (2001): Europeans and languages. Special Eurobarometer 54.

[24] European Commission (2005): Europeans and languages. Eurobarometer 237.

[25] European Commission (2006): Europeans and their languages. Special Eurobarometer 243.

[26] Fidrmuc, J. and J. Fidrmuc (2008), "Foreign Languages and Trade: What are you sinking about?", mimeo.

[27] Financial Times (2005): Fewer skilled graduates may hinder China. By Geoff Dyer and Khozem Merchant. Published: October 6. Available at: http://www.ft.com/cms/s/0/7ca87c34-369a-11da-bedc00000e2511c8.html?nclick_check=1

[28] Frankel, J., and Rose, A., (2002): "An estimate of the effect of common currencies on trade and income". Quarterly Journal of Economics 117,437-466.

[29] Gentzkow, Matthew (2006), "Television and Voter Turnout". Quarterly Journal of Economics, 121(3), pp. Available from http://faculty.chicagogsb.edu/matthew.gentzkow/research/television_turnout.pdf 
[30] Gentzkow, Matthew and Jesse Shapiro: Preschool television viewing and adolescent test scores historical evidence from the Coleman Study. Quarterly Journal of Economics. CXXIII (1). February 2008. http://faculty.chicagogsb.edu/matthew.gentzkow/research/television061007_qje.pdf

[31] González, L. (2005): "Non-parametric bounds on the returns to language skills." Journal of Applied Econometrics, 20: 771-795.

[32] Gottlieb, H. (1997): Subtitles, translation $\mathcal{E}$ idioms. PhD thesis, University of Copenhagen. ISBN 87-89065-39-5.

[33] Graddol, D. (1997): The future of English? A guide to forecasting the popularity of the English language in the 21st century. Published by the British Council, available at: http://www.britishcouncil.org/learning-elt-future.pdf

[34] Graddol, D. (2006): English next. Published by the British Council, available at: http://www.britishcouncil.org/learning-research-english-next.pdf

[35] Grenier G. (1984): "The Effects of language characteristics on the wages of Hispanic-American males". The Journal of Human Resources 19: 35-52

[36] Grinblatt M., and M. Keloharju (2001), "How distance, language and culture influence stockholdings and trades", Journal of Finance 56, 1053-1073.

[37] Harmon, C.P., Hessel Oosterbeek and Ian Walker (2003): "The returns to education: microeconomics". Journal of Economic Surveys, vol. 17, issue 2, pages 115-156.

[38] Heckman James J. (1979): "Sample selection bias as a specification error," . Econometrica 47, 153-161

[39] Galán, D. (2003): "La lengua española en el cine”. Anuario del Instituto Cervantes: El Español en el mundo.

[40] Gartzke, E. (1998): "Kant We All Just Get Along?: Opportunity, Willingness, and the Origins of the Democratic Peace." American Journal of Political Science, vol. 42, issue 1, pp. 1-27.

[41] Gartzke, E. (2000): "Preferences and the Democratic Peace.". International Studies Quarterly vol. 44, issue 2, pp 191-210.

[42] Kim, Soo Yeon, Bruce Russett (1996): "The new politics of voting alignments in the United Nations General Assembly". International Organization. vol. 50, issue 4, pp. 629 - 652.

[43] Koussoudji, S.A. (1988): "English language ability and the labor market opportunities of Hispanic and East Asian immigrant men". Journal of Labor Economics vol.6 , no.2, pp. . 
[44] Levinsohn, J. (2004), "Globalization and the Returns to Speaking English in South Africa", NBER working paper 10985.

[45] McManus WS. (1985): "Labor market costs of language disparity: an interpretation of Hispanic earnings differences". The American Economic Review 75: 818-827.

[46] McManus W, Gould W, Welch F. (1983): "Earnings of Hispanic men: The role of English language proficiency". Journal of Labor Economics 1(2): 101-130.

[47] Mera, M. (1998): "Read my lips: re-evaluating subtitling and dubbing in Europe". Links Ej Letters, vol. 6 , pp. $73-85$.

[48] MCG (2007), "Dubbing and subtitling needs and practices in the European audiovisual industry", Report for the Information Society and Media Directorate General of the EuropeanCommission.

[49] Newsweek (2007): English for everyone. In issue 20-27 August. By Jonathan Adams and Max Hirsch.

[50] Nuffield Foundation (2000): The nuffield languages inquiry: languages: the next generation.

[51] Olken, Benjamin (2006), "Do Television and Radio Destroy Social Capital? Evidence from Indonesian Villages ", NBER Working Paper 12561. Available from http://www.nber.org/ ${ }^{\sim}$ bolken/televisionandsocialcapital.pdf

[52] Pagano, M., A.A. Röell, and J. Zechner (2002), "The Geography of Equity Listing: Why Do Companies List Abroad?". The Journal of Finance 57, 2651-2694.

[53] Portes R., and Helene Rey, (2005), "The Determinants of Cross-Border Equity Flows". Journal of International Economics 65, 269-296.

[54] Reimers CW. (1983): "Labor Market Discrimination Against Hispanic and Black Men". The Review of Economics and Statistics 65(4): 570-579.

[55] Rendón, S. (2007): "The Catalan premium: language and employment in Catalonia". Journal of Population Economics, vol. 20, pp. 669-686.

[56] Shapiro, J.M and Matthew Gentzkow (2004): "Media, Education, and Anti-Americanism in the Muslim World". Journal of Economic Perspectives. Summer, 2004. http://faculty.chicagogsb.edu/matthew.gentzkow/research/AntiAm.pdf

[57] Sianesi, B. and John van Reenen (2003): "The returns to education: macroeconomics". Journal of Economic Surveys, vol. 17, issue 2, pages 157-200. 
[58] Stromberg, David (2004), "Radio's Impact on Public Spending", Quarterly Journal of Economics, 119(1) Available at http://www.iies.su.se/ stromber/Radio.pdf

[59] Szarkowska, A. (2005): "The power of film translation". Translation Journal, vol. 9, no. 2.

[60] Tesar, L. and Ingrid Werner (1995): "Home bias and high turnover". Journal of International Money and Finance, vol. 14, no. 4, pp. 467-492.

[61] Van Huyck, J., Joseph Cook and Raymond Battalio (1997): "Adaptive behavior and coordination failure." Journal of Economic Behavior and Organization, vol. 32, pp. 483-503.

[62] Williams (2006), "The Economic returns to multiple language usage in Western Europe", CEPS/INSTEAD working paper. http://www.ceps.lu/iriss/documents/irisswp62.pdf 


\begin{tabular}{lc} 
Country & Film translation \\
mode \\
\hline Bustria & Dubbing \\
Bulgaria & Dubbing / Subtitling* \\
Cyprus & Voice over \\
Czech Rep & Subtitling \\
Denmark & Dubbing \\
Estonia & Subtitling \\
Finland & Subtitling/Dubbing** \\
France & Subtitling \\
Germany & Dubbing \\
Greece & Dubbing \\
Hungary & Subtitling \\
Iceland & Dubbing \\
Italy & Subtitling \\
Japan & Dubbing \\
South Korea & Dubbing \\
Latvia & Subtitling \\
Lithuania & Voice over \\
Luxembourg & Voice over \\
Malta & Dubbing \\
Mexico & Subtitling*** \\
Netherlands & Subtitling \\
Norway & Subtitling \\
Poland & Subtitling \\
Portugal & Voice over \\
Romania & Subtitling \\
Slovak Republic & Subtitling \\
Slovenia & Dubbing \\
Spain & Subtitling \\
Sweden & Dubbing \\
Switzerland & Subtitling \\
Turkey & Dubbing \\
\hline Table & Dubbing \\
\hline
\end{tabular}

\section{Table 1. Foreign Translation Mode across EU and OECD}

\section{Countries}

Sources: MCG (2007) report for the EU Commission and Wikipedia. * Dubbing in Wallonia, subtitling in Flanders. ** Subtitles for $2 / 3$ of the programs and voice over for $1 / 3$ of the programs. ${ }^{* * *}$ Most films are in original English version without subtitles. 


\begin{tabular}{|c|c|c|c|c|c|c|c|c|c|}
\hline & & \multicolumn{2}{|c|}{ National } & \multicolumn{2}{|c|}{$\begin{array}{c}\text { Non-national (other } \\
\text { European) }\end{array}$} & \multicolumn{2}{|c|}{ USA } & \multicolumn{2}{|c|}{ Other } \\
\hline & & Total & Prime-time & Total & Prime-time & Total & Prime-time & Total & Prime-time \\
\hline \multirow[t]{2}{*}{ Flanders - Belgium } & Public & 11,6 & 25 & 26,2 & 27,2 & 44,4 & 38,2 & 17,8 & 9,6 \\
\hline & Commercial & 5,1 & 11,9 & 10 & 4,4 & 79,5 & 82,3 & 5,4 & 1,4 \\
\hline \multirow[t]{2}{*}{ Wallonia - Belgium } & Public & - & - & 53,5 & 85,4 & 35,4 & 14,6 & 11,1 & - \\
\hline & Commercial & - & - & 21 & 37 & 75,6 & 63 & 3,4 & \\
\hline \multirow[t]{2}{*}{ Netherlands } & Public & 28,3 & 44,6 & 30 & 21,7 & 36,1 & 31,6 & 5,6 & 2,1 \\
\hline & Commercial & 12,6 & 20,2 & 6,4 & 9 & 78,8 & 67,6 & 2,2 & 3,2 \\
\hline \multirow[t]{2}{*}{ Germany } & Public & 50 & 77,4 & 25 & 18,5 & 19,6 & 4,1 & 5,4 & - \\
\hline & Commercial & 11 & 21,8 & 9,6 & 7,7 & 76,3 & 69,2 & 3,1 & 1,3 \\
\hline \multirow[t]{2}{*}{ France } & Public & 22 & 57,7 & 25,1 & 22,1 & 52,9 & 20,2 & - & - \\
\hline & Commercial & 29,9 & 47,3 & 8,2 & - & 60,7 & 52,7 & 1,2 & - \\
\hline \multirow[t]{2}{*}{ Italy } & Public & 28 & 16,2 & 29,3 & 31,6 & 42,3 & 52,2 & 0,4 & - \\
\hline & Commercial & 19,8 & 19 & 7,5 & 5,3 & 61,9 & 73 & 10,8 & 2,7 \\
\hline
\end{tabular}

TABLE 2: Origin of fiction

Percentage of broadcasting time devoted to fiction: January 1997

Source: De Bens and de Smaele (2001) 


\begin{tabular}{|c|c|c|c|c|c|c|}
\hline & & EC (200 & Survey & TOEF & 2006) & \\
\hline & & Raw Score & Ranking & Raw Score & Ranking & Ranking \\
\hline DK & Denmark & 86 & 4 & 265 & 1 & 1 \\
\hline NL & Netherlands & 87 & 3 & 262 & 2 & 2 \\
\hline IS & Iceland & & & 262 & 3 & 3 \\
\hline AT & Austria & 58 & 9 & 258 & 4 & 4 \\
\hline $\mathrm{BE}$ & Belgium & 59 & 8 & 257 & 5 & 5 \\
\hline NO & Norway & & & 257 & 6 & 6 \\
\hline $\mathrm{SI}$ & Slovenia & 57 & 10 & 256 & 7 & 7 \\
\hline $\mathrm{FI}$ & Finland & 63 & 6 & 255 & 8 & 8 \\
\hline SW & Sweden & 89 & 1 & 254 & 9 & 9 \\
\hline $\mathrm{CH}$ & Switzerland & & & 252 & 10 & 10 \\
\hline DE & Germany & 56 & 11 & 251 & 11 & 11 \\
\hline PT & Portugal & 32 & 16 & 251 & 12 & 12 \\
\hline RO & Romania & 29 & 19 & 251 & 13 & 13 \\
\hline LV & Latvia & 39 & 14 & 245 & 14 & 14 \\
\hline EE & Estonia & 46 & 13 & 243 & 15 & 15 \\
\hline SK & Slovak Republic & 32 & 17 & 243 & 16 & 16 \\
\hline BG & Bulgaria & 23 & 24 & 242 & 17 & 17 \\
\hline CZ & Czech Rep & 24 & 23 & 239 & 18 & 18 \\
\hline FR & France & 36 & 15 & 238 & 19 & 19 \\
\hline $\mathrm{HU}$ & Hungary & 23 & 25 & 237 & 20 & 20 \\
\hline LT & Lithuania & 32 & 18 & 234 & 21 & 21 \\
\hline PL & Poland & 29 & 20 & 234 & 22 & 22 \\
\hline$M X$ & Mexico & & & 234 & 23 & 23 \\
\hline EL & Greece & 48 & 12 & 233 & 24 & 24 \\
\hline SP & Spain & 27 & 22 & 233 & 25 & 25 \\
\hline $\mathrm{CY}$ & Cyprus & 76 & 5 & 225 & 26 & 26 \\
\hline $\mathrm{KR}$ & Korea & & & 218 & 27 & 27 \\
\hline TR & Turkey & 17 & 26 & 212 & 28 & 28 \\
\hline IT & Italy & 29 & 21 & 196 & 29 & 29 \\
\hline JP & Japan & & & 192 & 30 & 30 \\
\hline MT & Malta & 88 & 2 & & & \\
\hline LU & Luxembourg & 60 & 7 & & & \\
\hline
\end{tabular}

Table 3. English Levels by Country

The TOEFL scores are overall averages for test-takers resident in each country in 2006. Source: TOEFL web-site (http://www.toefl.com)

The EU Survey variable is the percentage of people in each country that mentions English when asked "Which languages do you speak well enough in order to be able to have a conversation, excluding your mother tongue?", as reported in EU (2006) "Eurobarometer 243: Europeans and their Languages"
(pg.
13).
Source:
European
Union
web-site:

http://ec.europa.eu/public_opinion/archives/ebs/ebs_243_en.pdf. 


\begin{tabular}{|c|c|c|c|c|c|c|c|c|c|c|c|c|c|c|}
\hline & Country & $\begin{array}{l}\text { Language } \\
\text { similarity }\end{array}$ & $\begin{array}{c}\text { Years of } \\
\text { English } \\
\text { education at } \\
\text { school }\end{array}$ & $\begin{array}{l}\text { Pupil teacher } \\
\text { ratio }\end{array}$ & $\begin{array}{l}\text { Public } \\
\text { education } \\
\text { capita }\end{array}$ & $\begin{array}{l}\text { GDP Total } \\
\text { (\$billion) }\end{array}$ & Population & $\begin{array}{l}\text { GDP per } \\
\text { capita (\$) }\end{array}$ & $\begin{array}{l}\text { Trade to GDP } \\
\text { ratio }\end{array}$ & $\begin{array}{l}\text { Tourism } \\
\text { receipts as } \\
\text { percentage of } \\
\text { GDP }\end{array}$ & $\begin{array}{c}\text { TV Sets per } \\
10,000 \\
\text { inhabitants }\end{array}$ & $\begin{array}{c}\text { Average } \\
\text { Annual TV } \\
\text { viewing } \\
\text { (hours) }\end{array}$ & $\begin{array}{c}\text { Average } \\
\text { Annual } \\
\text { Cinema } \\
\text { Attendance } \\
\text { per Person }\end{array}$ & $\begin{array}{c}\text { Percentage of } \\
\text { movies } \\
\text { subtitled in } \\
\text { the cinema }\end{array}$ \\
\hline$\overline{\mathrm{AT}}$ & Austria & 578 & 13 & 12,41 & $2.053,3$ & $\$ 238$ & 8,2 & $\$ 29.436$ & 56,85 & 5,08 & 519,242 & 955 & 2,09 & $7 \%$ \\
\hline $\mathrm{BE}$ & Belgium & 415 & 8 & 11,49 & & $\$ 289$ & 10,5 & $\$ 27.892$ & 106,39 & 2,66 & 455,423 & 1194 & 2,26 & $59 \%$ \\
\hline$B G$ & Bulgaria & 228 & 8 & 16,23 & 135,1 & $\$ 42$ & 7,67 & $\$ 5.359$ & 74,72 & 8,83 & 444,295 & 1204 & 0,31 & \\
\hline $\mathrm{CY}$ & Cyprus & 581 & 9 & & & & 0,85 & & & & & 979 & & $100 \%$ \\
\hline$C Z$ & Czech Rep & 241 & 10 & 16,25 & 446,4 & $\$ 172$ & 10,28 & $\$ 16.759$ & 73,57 & 3,7 & 332,568 & 1253 & & $100 \%$ \\
\hline DK & Denmark & 593 & 9 & & $3.712,5$ & $\$ 160$ & 5,44 & $\$ 29.863$ & 49,49 & 2,13 & 574,558 & 930 & 2,32 & $89 \%$ \\
\hline $\mathrm{EE}$ & Estonia & 0 & 12 & 11,4 & 513,9 & $\$ 16$ & 1,32 & $\$ 11.780$ & 85,56 & 6,89 & 453,863 & 1350 & 1,18 & $94 \%$ \\
\hline $\mathrm{FI}$ & Finland & 0 & 12 & 15,53 & $2.700,0$ & $\$ 139$ & 5,23 & $\$ 26.785$ & 42,07 & & 612,675 & 1028 & 1,27 & $82 \%$ \\
\hline FR & France & 236 & 8 & & $2.105,7$ & $\$ 1.574$ & 64,1 & $\$ 26.401$ & 27,66 & 1,98 & 573,727 & 1253 & 2,99 & $14 \%$ \\
\hline $\mathrm{DE}$ & Germany & 578 & 9 & 14,12 & $1.403,4$ & $\$ 2.173$ & 82,4 & $\$ 26.397$ & 41,21 & 1,05 & 623,552 & 1283 & 1,66 & $25 \%$ \\
\hline $\mathrm{EL}$ & Greece & 162 & 9 & 11,06 & 656,5 & $\$ 208$ & 11,12 & $\$ 19.008$ & 21,95 & 4,84 & 238,095 & 1490 & & $96 \%$ \\
\hline $\mathrm{HU}$ & Hungary & 0 & 9 & & & & 10,06 & & & & 441,691 & 1590 & 1,16 & $64 \%$ \\
\hline is & Iceland & 546 & . & 10,44 & $3.445,7$ & $\$ 9$ & & $\$ 30.176$ & 77,16 & 3,86 & 330,259 & & & \\
\hline IT & Italy & 247 & 7 & 10,62 & $1.470,1$ & $\$ 1.489$ & 59,09 & $\$ 25.879$ & 41,17 & 3,88 & 521,488 & 1624 & 1,83 & $7 \%$ \\
\hline $\mathrm{JP}$ & Japan & 0 & & 10,49 & $1.417,5$ & $\$ 3.462$ & & $\$ 27.210$ & 28,28 & 2 & 678,873 & & & \\
\hline LV & Latvia & 197 & 10 & & & & 2,29 & & & & 532,751 & 1241 & 0,9 & \\
\hline LT & Lithuania & 216 & 9 & 29,02 & 387,8 & $\$ 10$ & 3,57 & $\$ 3.018$ & 42,39 & 0,72 & 472,616 & 1210 & 0,73 & $100 \%$ \\
\hline LU & Luxembourg & 350 & 13 & 14,07 & $4.228,0$ & $\$ 25$ & 0,48 & $\$ 56.486$ & 65,37 & & 608,232 & . & 2,7 & \\
\hline MT & Malta & & 11 & & & & 0,4 & & & & 702,575 & . & $2, r$ & $100 \%$ \\
\hline$M X$ & Mexico & 240 & & 11,33 & & $\$ 927$ & & $\$ 9.110$ & 152,59 & & 241,048 & & & \\
\hline $\mathrm{NL}$ & Netherlands & 608 & 13 & & $1.953,4$ & $\$ 468$ & 16,57 & $\$ 29.190$ & 77,4 & 1,66 & 493,692 & 1186 & 1,38 & $96 \%$ \\
\hline NO & Norway & 548 & & & $3.453,5$ & $\$ 160$ & & $\$ 35.258$ & 37,06 & 1,14 & 441,977 & 942 & 2,59 & $89 \%$ \\
\hline $\mathrm{PL}$ & Poland & 239 & 9 & 11,54 & 365,0 & $\$ 428$ & 38,51 & $\$ 11.118$ & 39,88 & 2,07 & 338,451 & 1466 & 0,84 & $87 \%$ \\
\hline PT & Portugal & 240 & 7 & 10,53 & $1.236,9$ & $\$ 189$ & 10,64 & $\$ 18.187$ & 35,45 & 4,29 & 313,269 & 1289 & 1,15 & $93 \%$ \\
\hline RO & Romania & 227 & 10 & 16,99 & & $\$ 155$ & 22,27 & $\$ 7.061$ & 40,05 & & 235,11 & 1478 & 0,13 & $100 \%$ \\
\hline SK & Slovak Republii & 250 & 9 & 17,51 & 330,8 & $\$ 69$ & 54,47 & $\$ 12.875$ & 87,91 & & 482,416 & 1222 & 0,63 & $100 \%$ \\
\hline $\mathrm{SI}$ & Slovenia & 249 & 10 & 15,55 & 974,8 & $\$ 37$ & 20,09 & $\$ 18.297$ & 71,88 & 5,15 & 353,058 & 1046 & 1,34 & $100 \%$ \\
\hline $\mathrm{KR}$ & South Korea & 0 & & 18,9 & 655,4 & $\$ 830$ & & $\$ 17.479$ & 17,07 & 0,27 & 326,885 & & & \\
\hline $\mathrm{SP}$ & Spain & 240 & 10 & 13,75 & $1.050,1$ & $\$ 945$ & 45,06 & $\$ 22.462$ & 28,51 & 4,25 & 401,577 & 1320 & 2,78 & $8 \%$ \\
\hline sw & Sweden & 591 & 12 & 10,05 & $2.890,7$ & $\$ 240$ & 9,12 & $\$ 26.832$ & 47,22 & & 510,998 & 894 & 1,64 & $100 \%$ \\
\hline $\mathrm{CH}$ & Switzerland & 426 & . & 12,78 & & $\$ 226$ & & $\$ 31.051$ & 47,13 & 2,97 & 441,982 & 1064 & 2,2 & $25 \%$ \\
\hline TR & Turkey & 0 & & & 163,4 & $\$ 474$ & & $\$ 6.865$ & 31,91 & 5,02 & 300,259 & & & \\
\hline
\end{tabular}

\section{Table 4. Sample Descriptio}

Sourcces: The language similarity is taken from Dyen et al. (1992) for indoeuropean languages. The variable takes a value of zero (minimum similarity) for non-indoeuropean languages. The trade to GDP ratio, tourism receipts, pupil / teacher ratios, data on public education expenditure per capita, GDP, population are all taken from the IMD world competitiveness yearbook data set (http://www.imd.ch/research/publications/wcy/index.cfm), and are reported as averages per country over the sample period. The years of English variable is taken from Eurostat (http://epp.eurostat.ec.europa.eu). 


\begin{tabular}{|c|c|c|c|c|c|c|c|c|c|c|c|}
\hline & GDP per Capita & Pisa Score & $\begin{array}{c}\text { Public } \\
\text { Expenditure in } \\
\text { Education per } \\
\text { Capita }\end{array}$ & $\begin{array}{l}\text { Years of Formal } \\
\text { English } \\
\text { Education }\end{array}$ & TOEFL Score & $\begin{array}{l}\text { Adjusted } \\
\text { TOEFL Score }\end{array}$ & $\begin{array}{l}\text { EU Survey } \\
\text { Scores }\end{array}$ & $\begin{array}{c}\text { Pupil-to- } \\
\text { Teacher Ratio }\end{array}$ & $\begin{array}{l}\text { TV sets per } \\
\text { Capita }\end{array}$ & $\begin{array}{l}\text { Average Annual } \\
\text { TV Viewing } \\
\text { (hours) }\end{array}$ & $\begin{array}{l}\text { Average Annual } \\
\text { Cinema } \\
\text { Attendance per } \\
\text { person }\end{array}$ \\
\hline \multicolumn{12}{|l|}{ Dubbing Countries } \\
\hline Number of Countries & 16 & 18 & 16 & 14 & 18 & 17 & 15 & 16 & 18 & 13 & 13 \\
\hline Mean & 22186,1 & 486,5 & 713,4 & 9,7 & 298,0 & 160,6 & 32,0 & 14,1 & 471,9 & 1285,8 & 1,5 \\
\hline Median & 22100,3 & 488,5 & 324,9 & 9,0 & 237,0 & 160,4 & 29,9 & 14,2 & 463,2 & 1253,0 & 1,2 \\
\hline Standard Deviation & 0,6 & 24,6 & 852,0 & 1,8 & 134,3 & 18,9 & 14,0 & 8,3 & 105,4 & 181,0 & 0,8 \\
\hline Min & 5735,7 & 402,0 & 0,0 & 7,0 & 183,0 & 116,6 & 7,1 & 0,0 & 300,3 & 955,0 & 0,3 \\
\hline Max & 69806,2 & 556,0 & 4321,9 & 13,0 & 602,0 & 190,9 & 66,0 & 32,2 & 678,9 & 1624,0 & 3,0 \\
\hline \multicolumn{12}{|l|}{ Subtitling Countries } \\
\hline Number of Countries & 12 & 12 & 12 & 11 & 13 & 12 & 11 & 12 & 13 & 9 & 8 \\
\hline Mean & 23138,1 & 488,5 & 1209,4 & 10,0 & 312,4 & 176,1 & 58,6 & 10,3 & 423,3 & 1119,1 & 1,6 \\
\hline Median & 24608,4 & 497,0 & 836,7 & 10,0 & 252,0 & 186,3 & 60,0 & 11,7 & 442,0 & 1046,0 & 1,4 \\
\hline Standard Deviation & 0,5 & 36,9 & 1123,1 & 1,8 & 135,3 & 22,7 & 22,2 & 6,0 & 147,1 & 173,5 & 0,8 \\
\hline Min & 5163,0 & 396,0 & 0,0 & 7,0 & 210,0 & 126,4 & 21,0 & 0,0 & 235,1 & 930,0 & 0,1 \\
\hline $\operatorname{Max}$ & 42467,7 & 547,0 & 4107,6 & 13,0 & 616,0 & 201,4 & 89,0 & 20,6 & 702,6 & 1478,0 & 2,6 \\
\hline $\begin{array}{l}\text { Difference in Median (Dubbing minus Subtitling) } \\
\text { p-value }\end{array}$ & $\begin{array}{l}-2508,0 * \\
(0,0575)\end{array}$ & $\begin{array}{r}-8,5^{* *} \\
(0,0226)\end{array}$ & $\begin{array}{c}-511,7^{\star * *} \\
(0,0016)\end{array}$ & $\begin{array}{c}-1,0 \\
(0,1300)\end{array}$ & $\begin{array}{l}-15,0 * * * \\
(0,0000)\end{array}$ & $\begin{array}{l}-25,9 * * * \\
(0,0000)\end{array}$ & $\begin{array}{l}-30,1 * * \\
(0,0000)\end{array}$ & $\begin{aligned} 2,5 * * * \\
(0,0000)\end{aligned}$ & $\begin{array}{c}21,3 * * * \\
(0,0012)\end{array}$ & $\begin{array}{l}207,0 * \star * \\
(0,0000)\end{array}$ & $\begin{array}{c}-0,2 * \\
(0,0856)\end{array}$ \\
\hline
\end{tabular}

TABLE 5: Characteristics of the Sample, depending on the Translation Method

Sourcces: GDP per capita is from the IMD world competitiveness yearbook data set (http://www.imd.ch/research/publications/wcy/index.cfm). The years of English variable is taken from Eurostat (http://epp.eurostat.ec.europa.eu). Data on film translation mode is from Wikipedia. Tests of differences in medians are based on a non-paramteric Wilcoxon test. 
Size of the national language(s) in 1933, in logs Size of the economy, 1933

(Imports + Exports)/Pop 1933

GDP per capita, 1933, logs

Country suffered dictatorship 1930-50

Democracy Index

Similarity between local language and English

Distance to relevant English speaking area, logs

\section{Constant}

Observations

Pseudo R-squared

$-0.697^{\star *}$

$[0.288]$

$-0.000^{*}$

[0.000]

0,011

0,011
$[0.008]$

\section{$-0.655^{*}$}

$-0.989^{\star \star \star}$

0.371

[0.290]

$[0.328]$

[0.000]

0,085
$[0.570]$

Robust standard errors in brackets

${ }^{* * *} p<0.01,{ }^{* *} p<0.05,{ }^{*} p<0.1$

\section{Table 6. Determinants of Subtitling}

This table reports probit regression results on the countries' cross-section, where the dependent variable is an indicator ( $0=$ subtitles, $1=$ dubbing). The1933 economic and demographic data was downloaded Maddison's historical statistics (http://www.ggdc.net/maddison/): Size of the national language is obtained by computing the sum of the populations of the countries in which each language is spoken. Trade openness is calculated as the sum of imports and exports relative to GDP of the country. The democracy index is the Polity IV 1933 score for each country. The dictatorship score is a dummy variable $(0=$ Polity IV $>=+6$ "democracy", $1=$ Polity IV < +6 “dictatorship") following the standard Polity IV definitions: democracies ("no-dictatorships") are those countries between +6 and +10 in the -10 to +10 spectrum. The distance to the relevant English speaking area is computed as follows. For European countries, distance between the country's capital and London. For Mexico, distance between the capital and Los Angeles. For Asian countries, the variable is the average of the distance between London and Los Angeles and the respective capital. 


\begin{tabular}{|c|c|c|c|c|c|c|c|c|}
\hline & $\begin{array}{l}\text { EU Survey - } \\
\text { OLS Model } 1\end{array}$ & $\begin{array}{l}\text { EU Survey - } \\
\text { OLS Model } 2\end{array}$ & $\begin{array}{l}\text { EU Survey - } \\
\text { OLS Model } 3\end{array}$ & $\begin{array}{l}\text { EU Survey - } \\
\text { OLS Model } 4\end{array}$ & $\begin{array}{c}\text { EU Survey - } \\
\text { Treatment } \\
\text { Effects } \\
\text { Model } 1\end{array}$ & $\begin{array}{c}\text { EU Survey - } \\
\text { Treatment } \\
\text { Effects } \\
\text { Model } 2\end{array}$ & $\begin{array}{c}\text { EU Survey - } \\
\text { Treatment } \\
\text { Effects } \\
\text { Model } 3\end{array}$ & $\begin{array}{c}\text { EU Survey - } \\
\text { Treatment } \\
\text { Effects } \\
\text { Model } 4\end{array}$ \\
\hline Subtitles $(\mathrm{Y} / \mathrm{N})$ & $\begin{array}{c}15.683^{\star * *} \\
{[1.010]}\end{array}$ & $\begin{array}{c}12.942^{\star * *} \\
{[3.311]}\end{array}$ & $\begin{array}{c}15.075^{\star \star \star} \\
{[1.349]}\end{array}$ & $\begin{array}{c}13.424^{\star * *} \\
{[3.011]}\end{array}$ & & & & \\
\hline Subtitles $(Y / N)$ - Instrumented & & & & & $\begin{array}{c}25.154^{\star \star \star} \\
{[2.945]}\end{array}$ & $\begin{array}{c}17.754^{\star \star \star} \\
{[3.202]}\end{array}$ & $\begin{array}{c}20.405^{\star \star \star} \\
{[3.605]}\end{array}$ & $\begin{array}{c}18.399 \star \star \star \\
{[3.235]}\end{array}$ \\
\hline Similarity between local language and English & $\begin{array}{c}0.057^{\star \star \star *} \\
{[0.001]}\end{array}$ & $\begin{array}{c}0.051^{\star \star \star} \\
{[0.003]}\end{array}$ & $\begin{array}{c}0.060^{\star \star \star \star} \\
{[0.002]}\end{array}$ & $\begin{array}{c}0.053^{\star \star \star} \\
{[0.002]}\end{array}$ & $\begin{array}{c}0.053^{\star \star * *} \\
{[0.003]}\end{array}$ & $\begin{array}{c}0.048^{\star \star \star} \\
{[0.005]}\end{array}$ & $\begin{array}{c}0.056^{\star \star \star} \\
{[0.005]}\end{array}$ & $\begin{array}{c}0.050^{\star \star \star \star} \\
{[0.005]}\end{array}$ \\
\hline Years of English education at school & $\begin{array}{l}1.459^{*} \\
{[0.779]}\end{array}$ & $\begin{array}{c}0,49 \\
{[0.892]}\end{array}$ & $\begin{array}{c}0,946 \\
{[1.014]}\end{array}$ & $\begin{array}{c}0,408 \\
{[0.919]}\end{array}$ & $\begin{array}{c}0,944 \\
{[0.663]}\end{array}$ & $\begin{array}{c}0,382 \\
{[0.600]}\end{array}$ & $\begin{array}{c}0,803 \\
{[0.717]}\end{array}$ & $\begin{array}{c}0,286 \\
{[0.595]}\end{array}$ \\
\hline PISA education quality assessment & $\begin{array}{l}0.250^{\star \star \star \star} \\
{[0.020]}\end{array}$ & $\begin{array}{c}0.252^{\star \star \star \star} \\
{[0.026]}\end{array}$ & $\begin{array}{l}0.278^{\star \star \star} \\
{[0.019]}\end{array}$ & $\begin{array}{l}0.251^{\star \star \star} \\
{[0.023]}\end{array}$ & $\begin{array}{c}0.137^{\star \star \star \star} \\
{[0.022]}\end{array}$ & $\begin{array}{l}0.187^{\star \star \star} \\
{[0.048]}\end{array}$ & $\begin{array}{c}0.206^{\star \star \star} \\
{[0.045]}\end{array}$ & $\begin{array}{l}0.185^{\star \star \star} \\
{[0.048]}\end{array}$ \\
\hline Expenditure in public education per capita & & $\begin{array}{l}0.007^{\star \star \star \star} \\
{[0.002]}\end{array}$ & & $\begin{array}{l}0.007^{\star \star \star} \\
{[0.001]}\end{array}$ & & $\begin{array}{l}0.007^{\star \star \star \star} \\
{[0.001]}\end{array}$ & & $\begin{array}{l}0.007^{\star \star \star} \\
{[0.001]}\end{array}$ \\
\hline Pupil to teacher ratio & & & $\begin{array}{c}0,275 \\
{[0.242]}\end{array}$ & $\begin{array}{c}0,221 \\
{[0.224]}\end{array}$ & & & $\begin{array}{c}0,307 \\
{[0.250]}\end{array}$ & $\begin{array}{c}0,252 \\
{[0.250]}\end{array}$ \\
\hline Inverse Mills Ratio & & & & & $\begin{array}{c}-10.584^{\star \star \star} \\
{[1.579]}\end{array}$ & $\begin{array}{c}-7.794^{\star \star *} \\
{[1.884]}\end{array}$ & $\begin{array}{c}-8.570^{\star \star \star} \\
{[2.041]}\end{array}$ & $\begin{array}{c}-7.949 * \star \star \\
{[1.828]}\end{array}$ \\
\hline Constant & $\begin{array}{c}-119.316^{\star \star \star} \\
{[5.180]}\end{array}$ & $\begin{array}{c}-118.667^{\star \star \star} \\
{[7.405]}\end{array}$ & $\begin{array}{c}-134.971^{\star \star \star} \\
{[6.737]}\end{array}$ & $\begin{array}{c}-120.810^{\star \star \star} \\
{[6.365]}\end{array}$ & $\begin{array}{c}-62.142^{\star \star \star} \\
{[11.229]}\end{array}$ & $\begin{array}{c}-86.210 * \star \star \\
{[23.911]}\end{array}$ & $\begin{array}{c}-99.313^{\star \star \star} \\
{[22.678]}\end{array}$ & $\begin{array}{c}-88.009^{\star \star \star} \\
{[23.539]}\end{array}$ \\
\hline Observations & 169 & 115 & 115 & 115 & 143 & 115 & 115 & 115 \\
\hline Number of year & 11 & 9 & 9 & 9 & 11 & 9 & 9 & 9 \\
\hline R-squared & 0,725 & 0,721 & 0,646 & 0,723 & 0,782 & 0,759 & 0,694 & 0,761 \\
\hline St.Dev. of Dependent Variable & 22,37 & 22,37 & 22,37 & 22,37 & 22,37 & 22,37 & 22,37 & 22,37 \\
\hline
\end{tabular}

${ }^{* * *} p<0.01,{ }^{* \star} p<0.05,{ }^{*} p<0.1$

\section{Table 7: Factors influencing English quality --EU survey}

This table reports panel regressions in which the left hand side variable is the EU survey quality of English measurement. We estimate year fixed effects in all the regressions. Robust standard errors are in parentheses. In models 1, 2, 3 and 4 the subtitles dummy is assumed to be exogenous to English quality. In models 5, 6, 7 and 8, the subtitles variable is instrumented with a model including the dictatorship dummy and the size of the local language in 1933 (no constant). 


\begin{tabular}{|c|c|c|c|c|c|c|c|c|c|c|c|c|}
\hline & $\begin{array}{c}\text { TOEFL- } \\
\text { OLS Model } 1 \\
\end{array}$ & $\begin{array}{c}\text { TOEFL- } \\
\text { OLS Model } 2 \\
\end{array}$ & $\begin{array}{c}\text { TOEFL- } \\
\text { OLS Model } 3 \\
\end{array}$ & $\begin{array}{c}\text { TOEFL - } \\
\text { Treatment } \\
\text { Effects } \\
\text { Model } 1 \\
\end{array}$ & $\begin{array}{c}\text { TOEFL - } \\
\text { Treatment } \\
\text { Effects } \\
\text { Model } 2 \\
\end{array}$ & $\begin{array}{c}\text { TOEFL - } \\
\text { Treatment } \\
\text { Effects } \\
\text { Model } 3 \\
\end{array}$ & $\begin{array}{c}\text { Adjusted } \\
\text { TOEFL- OLS } \\
\text { Model } 1 \\
\end{array}$ & $\begin{array}{c}\text { Adjusted } \\
\text { TOEFL- OLS } \\
\text { Model } 2 \\
\end{array}$ & $\begin{array}{c}\text { Adjusted } \\
\text { TOEFL- OLS } \\
\text { Model } 3 \\
\end{array}$ & $\begin{array}{c}\text { Adjusted } \\
\text { TOEFL - } \\
\text { Treatment } \\
\text { Effects } \\
\text { Model } 1 \\
\end{array}$ & $\begin{array}{c}\text { Adjusted } \\
\text { TOEFL - } \\
\text { Treatment } \\
\text { Effects } \\
\text { Model } 2 \\
\end{array}$ & $\begin{array}{c}\text { Adjusted } \\
\text { TOEFL - } \\
\text { Treatment } \\
\text { Effects } \\
\text { Model } 3 \\
\end{array}$ \\
\hline Subtitles $(\mathrm{Y} / \mathrm{N})$ & $\begin{array}{c}8.168^{\star \star \star} \\
{[0.645]}\end{array}$ & $\begin{array}{c}8.352^{\star \star *} \\
{[0.852]}\end{array}$ & $\begin{array}{c}8.400^{\star * *} \\
{[0.804]}\end{array}$ & & & & $\begin{array}{c}3.240^{\star \star *} \\
{[0.616]}\end{array}$ & $\begin{array}{c}3.113^{\star * *} \\
{[0.906]}\end{array}$ & $\begin{array}{c}3.299 * \star \star \\
{[0.922]}\end{array}$ & & & \\
\hline Subtitles $(\mathrm{Y} / \mathrm{N})$ - Instrumented & & & & $\begin{array}{c}18.469^{\star \star \star \star} \\
{[3.867]}\end{array}$ & $\begin{array}{c}11.098^{\star \star \star} \\
{[3.710]}\end{array}$ & $\begin{array}{c}11.347^{\star \star \star} \\
{[3.813]}\end{array}$ & & & & $\begin{array}{l}8.739 * * \\
{[4.373]}\end{array}$ & $\begin{array}{c}3,332 \\
{[3.632]}\end{array}$ & $\begin{array}{c}4,056 \\
{[3.791]}\end{array}$ \\
\hline Similarity between local language and English & $\begin{array}{c}0.054^{\star \star \star} \\
{[0.004]}\end{array}$ & $\begin{array}{c}0.063^{\star \star *} \\
{[0.006]}\end{array}$ & $\begin{array}{c}0.063^{\star \star *} \\
{[0.005]}\end{array}$ & $\begin{array}{c}0.053^{\star \star \star} \\
{[0.007]}\end{array}$ & $\begin{array}{c}0.061^{\star \star \star} \\
{[0.008]}\end{array}$ & $\begin{array}{c}0.062^{\star \star \star} \\
{[0.009]}\end{array}$ & $\begin{array}{c}0.055^{\star \star \star} \\
{[0.004]}\end{array}$ & $\begin{array}{c}0.060^{\star \star \star} \\
{[0.008]}\end{array}$ & $\begin{array}{c}0.062^{\star \star \star} \\
{[0.006]}\end{array}$ & $\begin{array}{c}0.047^{\star \star \star} \\
{[0.007]}\end{array}$ & $\begin{array}{c}0.060^{\star \star \star} \\
{[0.006]}\end{array}$ & $\begin{array}{c}0.061^{\star \star \star} \\
{[0.006]}\end{array}$ \\
\hline Years of English education at school & $\begin{array}{c}1.925^{\star \star \star} \\
{[0.337]}\end{array}$ & $\begin{array}{c}2.576^{\star \star *} \\
{[0.463]}\end{array}$ & $\begin{array}{c}2.550^{\star \star \star} \\
{[0.517]}\end{array}$ & $\begin{array}{c}0,409 \\
{[0.756]}\end{array}$ & $\begin{array}{c}2.563^{\star \star \star} \\
{[0.802]}\end{array}$ & $\begin{array}{c}2.532^{* * *} \\
{[0.802]}\end{array}$ & $\begin{array}{c}4.295^{\star \star \star} \\
{[0.765]}\end{array}$ & $\begin{array}{c}4.362^{\star \star \star} \\
{[1.052]}\end{array}$ & $\begin{array}{c}4.258^{\star \star \star} \\
{[1.123]}\end{array}$ & $\begin{array}{c}3.092^{* * *} \\
{[0.950]}\end{array}$ & $\begin{array}{c}4.362^{* * *} \\
{[1.003]}\end{array}$ & $\begin{array}{c}4.255^{\star \star *} \\
{[1.023]}\end{array}$ \\
\hline PISA education quality assessment & $\begin{array}{l}-0.055^{\star \star} \\
{[0.018]}\end{array}$ & $\begin{array}{l}-0,026 \\
{[0.015]}\end{array}$ & $\begin{array}{l}-0.027^{\star} \\
{[0.014]}\end{array}$ & $\begin{array}{l}-0,032 \\
{[0.038]}\end{array}$ & $\begin{array}{l}-0,038 \\
{[0.042]}\end{array}$ & $\begin{array}{l}-0,041 \\
{[0.042]}\end{array}$ & $\begin{array}{c}0.216^{\star \star \star} \\
{[0.047]}\end{array}$ & $\begin{array}{c}0.213^{\star \star \star} \\
{[0.050]}\end{array}$ & $\begin{array}{c}0.207 * \star \star \\
{[0.054]}\end{array}$ & $\begin{array}{l}0.243^{\star \star \star} \\
{[0.056]}\end{array}$ & $\begin{array}{c}0.212^{\star \star \star} \\
{[0.059]}\end{array}$ & $\begin{array}{l}0.204^{\star \star \star} \\
{[0.059]}\end{array}$ \\
\hline Expenditure in public education per capita & & $\begin{array}{c}0 \\
{[0.001]}\end{array}$ & $\begin{array}{c}0 \\
{[0.001]}\end{array}$ & & $\begin{array}{c}0 \\
{[0.001]}\end{array}$ & $\begin{array}{c}0 \\
{[0.001]}\end{array}$ & & $\begin{array}{l}0.003^{\star *} \\
{[0.001]}\end{array}$ & $\begin{array}{l}0.003^{\star *} \\
{[0.001]}\end{array}$ & & $\begin{array}{l}0.003^{\star \star} \\
{[0.001]}\end{array}$ & $\begin{array}{l}0.003^{\star \star} \\
{[0.001]}\end{array}$ \\
\hline Pupil to teacher ratio & & & $\begin{array}{c}0,077 \\
{[0.235]}\end{array}$ & & & $\begin{array}{c}0,094 \\
{[0.223]}\end{array}$ & & & $\begin{array}{c}0,247 \\
{[0.267]}\end{array}$ & & & $\begin{array}{c}0,252 \\
{[0.257]}\end{array}$ \\
\hline Inverse Gini index & $\begin{array}{l}16,452 \\
{[9.191]}\end{array}$ & $\begin{array}{l}-29.345^{\star} \\
{[13.093]}\end{array}$ & $\begin{array}{l}-30.259^{*} \\
{[13.652]}\end{array}$ & $\begin{array}{c}8,085 \\
{[24.295]}\end{array}$ & $\begin{array}{l}-28,027 \\
{[27.174]}\end{array}$ & $\begin{array}{l}-29,046 \\
{[27.880]}\end{array}$ & & & & & & \\
\hline Inverse Mills Ratio & & & & $\begin{array}{l}-8.118^{\star \star \star} \\
{[2.459]}\end{array}$ & $\begin{array}{l}-2,248 \\
{[2.500]}\end{array}$ & $\begin{array}{l}-2,404 \\
{[2.513]}\end{array}$ & & & & $\begin{array}{l}-5.559^{*} \\
{[3.017]}\end{array}$ & $\begin{array}{c}-0,18 \\
{[2.571]}\end{array}$ & $\begin{array}{l}-0,621 \\
{[2.722]}\end{array}$ \\
\hline Intercept & $\begin{array}{c}275.592^{\star \star \star} \\
{[7.568]}\end{array}$ & $\begin{array}{c}290.050^{\star \star \star *} \\
{[8.326]}\end{array}$ & $\begin{array}{c}290.335^{\star \star \star} \\
{[8.546]} \\
\end{array}$ & $\begin{array}{c}280.265^{\star \star \star} \\
{[16.833]}\end{array}$ & $\begin{array}{c}294.863^{\star \star \star} \\
{[17.904]}\end{array}$ & $\begin{array}{c}295.543^{\star \star \star} \\
{[18.059]}\end{array}$ & $\begin{array}{c}41,163 \\
{[29.897]} \\
\end{array}$ & $\begin{array}{c}41,858 \\
{[34.045]} \\
\end{array}$ & $\begin{array}{c}42,286 \\
{[32.988]} \\
\end{array}$ & $\begin{array}{r}39,043 \\
{[26.589]} \\
\end{array}$ & $\begin{array}{c}42,262 \\
{[29.175]} \\
\end{array}$ & $\begin{array}{c}43,682 \\
{[28.768]} \\
\end{array}$ \\
\hline Number of Observations & 244 & 197 & 197 & 209 & 197 & 197 & 244 & 197 & 197 & 209 & 197 & 197 \\
\hline Number of Years & 10 & 9 & 9 & 10 & 9 & 9 & 10 & 9 & 9 & 10 & 9 & 9 \\
\hline R-Squared & 0,502 & 0,543 & 0,543 & 0,989 & 0,99 & 0,99 & 0,493 & 0,585 & 0,587 & 0,964 & 0,97 & 0,97 \\
\hline St.Dev. of Dependent Variable & 134,6 & 134,6 & 134,6 & 134,6 & 134,6 & 134,6 & 95,08 & 95,08 & 95,08 & 95,08 & 95,08 & 95,08 \\
\hline
\end{tabular}

${ }^{* * *} \mathrm{p}<0.01,{ }^{* *} \mathrm{p}<0.05,{ }^{*} \mathrm{p}<0.1$

\section{TABLE 8: Factors influencing English quality adj. TOEFL and unadj. TOEFL}

This table reports panel regressions in which the left hand side variable of the first six models is the adjusted TOEFL English quality measurement and the last six is the unadjusted TOEFL. We include year fixed effects in all the regressions. Robust standard errors are in parentheses. In models 1 , 2, 3, 7, 8 and 9 the subtitles dummy is assumed to be exogenous to English quality. In models 4, 5, 6, 10, 11 and 12, the subtitles variable is instrumented with a model including the dictatorship dummy and the size of the local language in 1933 (no constant). 


\begin{tabular}{lcccc}
\hline Denmark & 64,77 & 46,17 & 78,32 & 53,95 \\
& 20,07 & 29,33 & 26,26 & 22,1 \\
Finland & 59,65 & 47,7 & 80,29 & 67,59 \\
& 24,52 & 29,47 & 23,07 & 20,63 \\
France & 30,6 & 14,55 & 56,84 & 48,01 \\
& 20,39 & 17,81 & 21,85 & 21,41 \\
Netherlands & 61,63 & 46,04 & 77,47 & 65 \\
& 21,44 & 25,67 & 21,54 & 22 \\
Norway & 73,26 & 56,3 & 82,03 & 66,36 \\
& 19,6 & 29,69 & 26,82 & 20,4 \\
Spain & 38,33 & 23,41 & 63,57 & 58,75 \\
& 23,08 & 25,5 & 21,66 & 23,3 \\
Sweden & 72,18 & 55,39 & 85,88 & 64,23 \\
& 19,65 & 28,04 & 22,31 & 20,43 \\
\hline Average subtitling & & & & \\
countries & 66,298 & 50,32 & 80,798 & 63,426 \\
Average dubbing & & & & \\
countries & 34,465 & 18,98 & 60,205 & 53,38 \\
Difference & & & & \\
subtitling-dubbing & 31,833 & 31,34 & 20,593 & 10,046 \\
\hline
\end{tabular}

\section{TABLE 9: Disaggregating by type of English skills}

The source for this table is Bonnet (2002). It summarizes the results of tests carried out amongst about 1,500 school pupils in the 14-to-16 age bracket by national authorities in the different countries. The tests are homogeneous across countries and were administered in 2001.

Dubbing countries are France and Spain. Subtitling countries are Denmark, Finland, Netherlands, Norway and Sweden. 


\begin{tabular}{|c|c|c|c|c|}
\hline & $\begin{array}{c}\text { EU Survey - } \\
\text { OLS } \\
\end{array}$ & $\begin{array}{c}\text { EU Survey - } \\
\text { Treatment } \\
\text { Effects }\end{array}$ & $\begin{array}{c}\text { Adjusted } \\
\text { TOEFL - OLS }\end{array}$ & $\begin{array}{c}\text { Adjusted } \\
\text { TOEFL - } \\
\text { Treatment } \\
\text { Effects }\end{array}$ \\
\hline Subtitles (Y/N) & $\begin{array}{c}-56.685^{\star \star} \\
{[18.737]}\end{array}$ & & $\begin{array}{c}19.436^{\star \star} \\
{[6.210]}\end{array}$ & \\
\hline Subtitles (Y/N) Instrumented & & $\begin{array}{c}-53.787^{\star \star \star} \\
{[14.979]}\end{array}$ & & $\begin{array}{c}-7,997 \\
{[90.499]}\end{array}$ \\
\hline Subtitles $(\mathrm{Y} / \mathrm{N}) \times$ Years English & $\begin{array}{l}7.195^{\star \star \star} \\
{[1.683]}\end{array}$ & & $\begin{array}{l}-1.413^{\star} \\
{[0.736]}\end{array}$ & \\
\hline Subtitles $(\mathrm{Y} / \mathrm{N})$ Instrumented $\mathrm{x}$ Years English & & $\begin{array}{l}7.369 * \star \star \\
{[1.415]}\end{array}$ & & $\begin{array}{l}-0,476 \\
{[8.667]}\end{array}$ \\
\hline Similarity between local language and English & $\begin{array}{c}0.056^{\star \star \star} \\
{[0.004]}\end{array}$ & $\begin{array}{c}0.053^{\star \star \star} \\
{[0.006]}\end{array}$ & $\begin{array}{c}0.039 * \star \star \\
{[0.005]}\end{array}$ & $\begin{array}{c}-0,008 \\
{[0.049]}\end{array}$ \\
\hline Years of English education at school & $\begin{array}{c}-2,178 \\
{[1.290]}\end{array}$ & $\begin{array}{c}-2.216^{\star \star \star} \\
{[0.828]}\end{array}$ & $\begin{array}{c}5.550^{\star \star \star *} \\
{[0.919]}\end{array}$ & $\begin{array}{c}8,854 \\
{[5.480]}\end{array}$ \\
\hline PISA education quality assessment & $\begin{array}{l}0.113^{\star \star} \\
{[0.048]}\end{array}$ & $\begin{array}{c}0,021 \\
{[0.062]}\end{array}$ & $\begin{array}{c}0,061 \\
{[0.035]}\end{array}$ & $\begin{array}{c}0,36 \\
{[0.357]}\end{array}$ \\
\hline Expenditure in public education per capita & $\begin{array}{l}0.007^{\star \star \star *} \\
{[0.001]}\end{array}$ & $\begin{array}{l}0.007^{\star \star \star} \\
{[0.001]}\end{array}$ & $\begin{array}{l}0.004^{\star \star *} \\
{[0.001]}\end{array}$ & $\begin{array}{c}-0,01 \\
{[0.009]}\end{array}$ \\
\hline Pupil to teacher ratio & $\begin{array}{l}-0,052 \\
{[0.128]}\end{array}$ & $\begin{array}{c}0,249 \\
{[0.176]}\end{array}$ & $\begin{array}{c}0,209 \\
{[0.189]}\end{array}$ & $\begin{array}{c}-8.082^{\star \star \star} \\
{[1.468]}\end{array}$ \\
\hline Inverse Mills Ratio & & $\begin{array}{l}-1,962 \\
{[2.483]}\end{array}$ & & $\begin{array}{c}-0,374 \\
{[16.393]}\end{array}$ \\
\hline Constant & $\begin{array}{l}-26,436 \\
{[31.577]} \\
\end{array}$ & $\begin{array}{c}15,896 \\
{[31.000]}\end{array}$ & $\begin{array}{c}109.704^{\star \star \star} \\
{[18.570]}\end{array}$ & $\begin{array}{c}61,214 \\
{[188.163]}\end{array}$ \\
\hline Observations & 115 & 115 & 139 & 139 \\
\hline R-squared & 9 & 9 & 9 & 9 \\
\hline Number of year & 22,37 & 22,37 & 95,08 & 95,08 \\
\hline St.Dev. of Dependent Variable & 0,817 & 0,745 & 0,534 & 0,319 \\
\hline
\end{tabular}

Rust standard errors in brackets

$* * * p<0.01,{ }^{* *} p<0.05,{ }^{*} p<0.1$

\section{TABLE 10: Interaction between formal education and subtitles effects OLS models EU survey and adj.}

\section{TOEFL}

This table reports panel regressions in which the left hand side variables are the EU survey and adjusted TOEFL quality of English measurements. We include year fixed effects in all the regressions. The treatment effect regressions are carried out with a model including the dictatorship dummy and 1933 language size variables (no constant). In all models, robust standard errors are in parentheses 
Panel 1: Controlling for TV Penetration (Number of TV Sets Per Capita)

\begin{tabular}{|c|c|c|c|c|c|c|c|c|c|c|}
\hline & $\begin{array}{c}\text { OLS } \\
\text { Model } 1 \text { - } \\
\text { E.U. } \\
\text { survey }\end{array}$ & $\begin{array}{c}\text { OLS } \\
\text { Model } 2 \text { - } \\
\text { E.U. } \\
\text { survey } \\
\end{array}$ & $\begin{array}{c}\text { OLS } \\
\text { Model } 3 \text { - } \\
\text { E.U. } \\
\text { survey }\end{array}$ & $\begin{array}{c}\text { OLS } \\
\text { Model } 4 \text { - } \\
\text { E.U. } \\
\text { survey }\end{array}$ & $\begin{array}{c}\text { Treatment } \\
\text { Effects - } \\
\text { EU } \\
\text { Survey }\end{array}$ & $\begin{array}{c}\text { OLS } \\
\text { Model } 1 \text { - } \\
\text { Adj. } \\
\text { TOEFL } \\
\end{array}$ & $\begin{array}{c}\text { OLS } \\
\text { Model } 2 \text { - } \\
\text { Adj. } \\
\text { TOEFL } \\
\end{array}$ & $\begin{array}{c}\text { OLS } \\
\text { Model } 3 \text { - } \\
\text { Adj. } \\
\text { TOEFL }\end{array}$ & $\begin{array}{c}\text { OLS } \\
\text { Model } 4 \text { - } \\
\text { Adj. } \\
\text { TOEFL }\end{array}$ & $\begin{array}{c}\text { Treatment } \\
\text { Effects - } \\
\text { Adj. } \\
\text { TOEFL }\end{array}$ \\
\hline Subtitles (Y/N) & $\begin{array}{c}-4.707^{\star \star} \\
{[2.092]}\end{array}$ & $\begin{array}{c}0,586 \\
{[2.893]}\end{array}$ & $\begin{array}{l}-7,289 \\
{[4.514]}\end{array}$ & $\begin{array}{c}1,508 \\
{[3.822]}\end{array}$ & & $\begin{array}{c}-29.574 * \star \star \\
{[5.887]}\end{array}$ & $\begin{array}{c}-27.480 \text { *** } \\
{[6.003]}\end{array}$ & $\begin{array}{c}-28.251^{\star \star \star} \\
{[6.261]}\end{array}$ & $\begin{array}{c}-27.956 * \star \star \\
{[6.315]}\end{array}$ & \\
\hline Subtitles $(\mathrm{Y} / \mathrm{N})$ Instrumented & & & & & $\begin{array}{l}12,268 \\
{[7.825]}\end{array}$ & & & & & $\begin{array}{c}-27.980^{* * *} \\
{[9.001]}\end{array}$ \\
\hline Subtitles $(\mathrm{Y} / \mathrm{N}) \times \mathrm{TV}$ penetration & $\begin{array}{c}0.048^{\star \star \star \star} \\
{[0.003]}\end{array}$ & $\begin{array}{c}0.030^{* \star *} \\
{[0.006]}\end{array}$ & $\begin{array}{c}0.052^{\star * *} \\
{[0.005]}\end{array}$ & $\begin{array}{l}0.029^{* *} \\
{[0.009]}\end{array}$ & & $\begin{array}{c}0.083^{\star * *} \\
{[0.014]}\end{array}$ & $\begin{array}{c}0.077^{\star \star *} \\
{[0.016]}\end{array}$ & $\begin{array}{c}0.081^{* * *} \\
{[0.015]}\end{array}$ & $\begin{array}{c}0.079 * * * \\
{[0.016]}\end{array}$ & \\
\hline Subtitles $(\mathrm{Y} / \mathrm{N})$ - Instrumented $\mathrm{x}$ TV penetration & & & & & $\begin{array}{c}0,015 \\
{[0.016]}\end{array}$ & & & & & $\begin{array}{c}0.079 * \star * \\
{[0.017]}\end{array}$ \\
\hline Similarity between local language and English & $\begin{array}{c}0.055^{\star * \star *} \\
{[0.001]}\end{array}$ & $\begin{array}{c}0.048^{\star * *} \\
{[0.003]}\end{array}$ & $\begin{array}{c}0.056^{* * *} \\
{[0.002]}\end{array}$ & $\begin{array}{c}0.051^{\star * *} \\
{[0.002]}\end{array}$ & $\begin{array}{c}0.049^{* \star *} \\
{[0.005]}\end{array}$ & $\begin{array}{c}0.052^{\star * *} \\
{[0.004]}\end{array}$ & $\begin{array}{c}0.056^{\star \star *} \\
{[0.007]}\end{array}$ & $\begin{array}{c}0.062^{\star \star *} \\
{[0.004]}\end{array}$ & $\begin{array}{c}0.059^{\star \star *} \\
{[0.005]}\end{array}$ & $\begin{array}{c}0.059 * \star * \\
{[0.006]}\end{array}$ \\
\hline Years of English education at school & $\begin{array}{c}2.185^{\star \star *} \\
{[0.502]}\end{array}$ & $\begin{array}{l}1.595^{\star *} \\
{[0.677]}\end{array}$ & $\begin{array}{l}1.929^{\star *} \\
{[0.780]}\end{array}$ & $\begin{array}{l}1.526^{*} \\
{[0.698]}\end{array}$ & $\begin{array}{l}1.399^{\star *} \\
{[0.642]}\end{array}$ & $\begin{array}{c}2.852^{\star \star \star} \\
{[0.496]}\end{array}$ & $\begin{array}{c}3.128^{\star \star *} \\
{[0.768]}\end{array}$ & $\begin{array}{c}3.210^{* * *} \\
{[0.643]}\end{array}$ & $\begin{array}{c}2.966^{\star * *} \\
{[0.827]}\end{array}$ & $\begin{array}{c}2.966^{* \star *} \\
{[1.001]}\end{array}$ \\
\hline PISA education quality assessment & $\begin{array}{c}0.141^{* * *} \\
{[0.025]}\end{array}$ & $\begin{array}{c}0.161^{* * *} \\
{[0.039]}\end{array}$ & $\begin{array}{c}0.156^{* * *} \\
{[0.033]}\end{array}$ & $\begin{array}{c}0.164^{* * *} \\
{[0.038]}\end{array}$ & $\begin{array}{l}0.134^{* *} \\
{[0.054]}\end{array}$ & $\begin{array}{c}0.106^{\star * *} \\
{[0.031]}\end{array}$ & $\begin{array}{l}0.107^{\star *} \\
{[0.037]}\end{array}$ & $\begin{array}{l}0.108^{* *} \\
{[0.040]}\end{array}$ & $\begin{array}{l}0.096^{*} \\
{[0.042]}\end{array}$ & $\begin{array}{c}0,096 \\
{[0.062]}\end{array}$ \\
\hline Pupil to teacher ratio & & & $\begin{array}{c}0,227 \\
{[0.210]}\end{array}$ & $\begin{array}{c}0,244 \\
{[0.262]}\end{array}$ & $\begin{array}{c}0,257 \\
{[0.212]}\end{array}$ & & & $\begin{array}{c}0,276 \\
{[0.237]}\end{array}$ & $\begin{array}{c}0,313 \\
{[0.258]}\end{array}$ & $\begin{array}{c}0,313 \\
{[0.248]}\end{array}$ \\
\hline Expenditure in public education per capita & & $\begin{array}{c}0.005^{\star * *} \\
{[0.001]}\end{array}$ & & $\begin{array}{c}0.005^{\star * *} \\
{[0.001]}\end{array}$ & $\begin{array}{c}0.006^{* * *} \\
{[0.001]}\end{array}$ & & $\begin{array}{c}0,002 \\
{[0.001]}\end{array}$ & & $\begin{array}{c}0,002 \\
{[0.001]}\end{array}$ & $\begin{array}{l}0.002^{*} \\
{[0.001]}\end{array}$ \\
\hline Inverse Mills Ratio & & & & & $\begin{array}{c}-7.249 * \star \star \\
{[1.742]}\end{array}$ & & & & & $\begin{array}{c}0,018 \\
{[2.895]}\end{array}$ \\
\hline Intercept & $\begin{array}{c}-73.692^{\star \star \star} \\
{[6.762]}\end{array}$ & $\begin{array}{c}-82.852^{\star * *} \\
{[11.930]}\end{array}$ & $\begin{array}{c}-83.862^{* * *} \\
{[7.690]}\end{array}$ & $\begin{array}{c}-87.422^{\star * \star} \\
{[11.608]}\end{array}$ & $\begin{array}{c}-72.583^{* * *} \\
{[25.821]}\end{array}$ & $\begin{array}{c}109.468 \text { *** } \\
{[18.516]}\end{array}$ & $\begin{array}{c}107.2466^{\star \star \star} \\
{[22.572]}\end{array}$ & $\begin{array}{c}102.705^{\star \star \star} \\
{[20.343]}\end{array}$ & $\begin{array}{c}109.311^{\star * *} \\
{[22.605]}\end{array}$ & $\begin{array}{c}109.273^{\star \star \star *} \\
{[31.485]}\end{array}$ \\
\hline Observations & 175 & 119 & 119 & 119 & 119 & 244 & 197 & 197 & 197 & 197 \\
\hline R-squared & 11 & 9 & 9 & 9 & 9 & 10 & 9 & 9 & 9 & 9 \\
\hline Number of year & 0,779 & 0,751 & 0,716 & 0,754 & 0,78 & 0,532 & 0,618 & 0,617 & 0,622 & 0,972 \\
\hline St.Dev. of Dependent Variable & 22,37 & 22,37 & 22,37 & 22,37 & 22,37 & 95,08 & 95,08 & 95,08 & 95,08 & 95,08 \\
\hline
\end{tabular}

Panel 2: Controlling for TV Viewing (Number of TV Hours per Capita)

\begin{tabular}{|c|c|c|c|c|c|c|c|c|c|c|}
\hline & $\begin{array}{c}\text { OLS } \\
\text { Model } 1 \text { - } \\
\text { E.U. } \\
\text { survey } \\
\end{array}$ & $\begin{array}{c}\text { OLS } \\
\text { Model } 2 \text { - } \\
\text { E.U. } \\
\text { survey } \\
\end{array}$ & $\begin{array}{c}\text { OLS } \\
\text { Model } 3 \text { - } \\
\text { E.U. } \\
\text { survey } \\
\end{array}$ & $\begin{array}{c}\text { OLS } \\
\text { Model } 4 \text { - } \\
\text { E.U. } \\
\text { survey } \\
\end{array}$ & $\begin{array}{c}\text { Treatment } \\
\text { Effects - } \\
\text { EU } \\
\text { Survey } \\
\end{array}$ & $\begin{array}{c}\text { OLS } \\
\text { Model } 1 \text { - } \\
\text { Adj. } \\
\text { TOEFL } \\
\end{array}$ & $\begin{array}{c}\text { OLS } \\
\text { Model } 2 \text { - } \\
\text { Adj. } \\
\text { TOEFL } \\
\end{array}$ & $\begin{array}{c}\text { OLS } \\
\text { Model } 3 \text { - } \\
\text { Adj. } \\
\text { TOEFL } \\
\end{array}$ & $\begin{array}{c}\text { OLS } \\
\text { Model } 4 \text { - } \\
\text { Adj. } \\
\text { TOEFL } \\
\end{array}$ & $\begin{array}{c}\text { Treatment } \\
\text { Effects - } \\
\text { Adj. } \\
\text { TOEFL } \\
\end{array}$ \\
\hline Subtitles $(\mathrm{Y} / \mathrm{N})$ & $\begin{array}{c}503.540^{\star \star *} \\
{[48.567]}\end{array}$ & $\begin{array}{c}465.724^{\star \star *} \\
{[84.407]}\end{array}$ & $\begin{array}{c}593.659 * * \star \\
{[107.514]}\end{array}$ & $\begin{array}{c}477.501^{\star * \star} \\
{[83.729]}\end{array}$ & & $\begin{array}{c}618.782^{\star * *} \\
{[101.214]}\end{array}$ & $\begin{array}{c}683.805^{\star \star *} \\
{[146.169]}\end{array}$ & $\begin{array}{c}592.003^{\star * *} \\
{[110.773]}\end{array}$ & $\begin{array}{r}674.855^{\star \star \star *} \\
{[145.143]}\end{array}$ & \\
\hline Subtitles $(\mathrm{Y} / \mathrm{N})$ Instrumented & & & & & $\begin{array}{c}438.729 * \star \star \\
{[120.164]}\end{array}$ & & & & & $\begin{array}{c}678.092^{\star \star \star} \\
{[139.167]}\end{array}$ \\
\hline Subtitles $(Y / N) \times$ TV viewing (hours per capita) in logs & $\begin{array}{c}-69.219 * * * \\
{[7.146]}\end{array}$ & $\begin{array}{c}-64.353^{\star * * *} \\
{[12.363]}\end{array}$ & $\begin{array}{c}-82.240^{\star \star *} \\
{[15.662]}\end{array}$ & $\begin{array}{c}-65.927^{\star \star *} \\
{[12.309]}\end{array}$ & & $\begin{array}{c}-86.636^{\star \star *} \\
{[14.530]}\end{array}$ & $\begin{array}{c}-95.893^{\star * * *} \\
{[20.920]}\end{array}$ & $\begin{array}{c}-82.850^{\star * *} \\
{[15.911]}\end{array}$ & $\begin{array}{c}-94.472^{\star * *} \\
{[20.859]}\end{array}$ & \\
\hline Subtitles (Y/N)- Instrumented x TV viewing (hours per capita) in logs & & & & & $\begin{array}{c}-60.037^{\star \star *} \\
{[17.236]}\end{array}$ & & & & & $\begin{array}{c}-95.202^{\star * *} \\
{[19.936]}\end{array}$ \\
\hline Similarity between local language and English & $\begin{array}{c}0.052^{\star \star *} \\
{[0.003]}\end{array}$ & $\begin{array}{c}0.048^{\star \star *} \\
{[0.008]}\end{array}$ & $\begin{array}{c}0.052^{\star \star *} \\
{[0.008]}\end{array}$ & $\begin{array}{c}0.051^{\star * *} \\
{[0.008]}\end{array}$ & $\begin{array}{c}0.049 * * * \\
{[0.008]}\end{array}$ & $\begin{array}{c}0.026^{\star \star *} \\
{[0.003]}\end{array}$ & $\begin{array}{c}0.039 * * * \\
{[0.008]}\end{array}$ & $\begin{array}{c}0.042^{* * *} \\
{[0.005]}\end{array}$ & $\begin{array}{c}0.043^{\star * *} \\
{[0.006]}\end{array}$ & $\begin{array}{c}0.044^{\star * *} \\
{[0.008]}\end{array}$ \\
\hline Years of English education at school & $\begin{array}{c}2.638^{\star * *} \\
{[0.312]}\end{array}$ & $\begin{array}{l}2.349^{\star *} \\
{[0.701]}\end{array}$ & $\begin{array}{l}2.236^{\star *} \\
{[0.737]}\end{array}$ & $\begin{array}{l}2.247^{\star *} \\
{[0.778]}\end{array}$ & $\begin{array}{l}2.123^{\star *} \\
{[0.847]}\end{array}$ & $\begin{array}{l}-0,497 \\
{[0.429]}\end{array}$ & $\begin{array}{c}0,091 \\
{[0.696]}\end{array}$ & $\begin{array}{l}-0,257 \\
{[0.699]}\end{array}$ & $\begin{array}{l}-0,225 \\
{[0.714]}\end{array}$ & $\begin{array}{l}-0,223 \\
{[1.077]}\end{array}$ \\
\hline PISA education quality assessment & $\begin{array}{c}0.107^{\star * *} \\
{[0.018]}\end{array}$ & $\begin{array}{l}0.110^{\star *} \\
{[0.047]}\end{array}$ & $\begin{array}{l}0.104^{\star *} \\
{[0.045]}\end{array}$ & $\begin{array}{l}0.112^{\star *} \\
{[0.044]}\end{array}$ & $\begin{array}{c}0,079 \\
{[0.064]}\end{array}$ & $\begin{array}{c}0,141 \\
{[0.107]}\end{array}$ & $\begin{array}{c}0,182 \\
{[0.159]}\end{array}$ & $\begin{array}{c}0,184 \\
{[0.142]}\end{array}$ & $\begin{array}{c}0,182 \\
{[0.147]}\end{array}$ & $\begin{array}{c}0,196 \\
{[0.126]}\end{array}$ \\
\hline Pupil to teacher ratio & & & $\begin{array}{c}0,3 \\
{[0.339]}\end{array}$ & $\begin{array}{c}0,268 \\
{[0.335]}\end{array}$ & $\begin{array}{c}0,268 \\
{[0.257]}\end{array}$ & & & $\begin{array}{l}0.531^{*} \\
{[0.245]}\end{array}$ & $\begin{array}{l}0.516^{\star} \\
{[0.244]}\end{array}$ & $\begin{array}{c}0,514 \\
{[0.329]}\end{array}$ \\
\hline Expenditure in public education per capita & & $\begin{array}{l}0.003^{*} \\
{[0.001]}\end{array}$ & & $\begin{array}{l}0.003^{* *} \\
{[0.001]}\end{array}$ & $\begin{array}{l}0.003^{* *} \\
{[0.002]}\end{array}$ & & $\begin{array}{c}-0,002 \\
{[0.001]}\end{array}$ & & $\begin{array}{l}-0,002 \\
{[0.002]}\end{array}$ & $\begin{array}{l}-0,002 \\
{[0.001]}\end{array}$ \\
\hline Inverse Mills Ratio & & & & & $\begin{array}{l}-3,571 \\
{[2.927]}\end{array}$ & & & & & $\begin{array}{c}1,436 \\
{[2.861]}\end{array}$ \\
\hline Intercept & $\begin{array}{c}-60.694^{\star * *} \\
{[13.443]}\end{array}$ & $\begin{array}{l}-63.578^{*} \\
{[32.393]}\end{array}$ & $\begin{array}{l}-61.638^{*} \\
{[31.955]}\end{array}$ & $\begin{array}{l}-67.736^{\star} \\
{[31.865]}\end{array}$ & $\begin{array}{c}-50,53 \\
{[34.322]}\end{array}$ & $\begin{array}{c}131.353^{\star *} \\
{[48.682]}\end{array}$ & $\begin{array}{l}108,268 \\
{[73.092]} \\
\end{array}$ & $\begin{array}{l}101,245 \\
{[63.282]}\end{array}$ & $\begin{array}{l}103,309 \\
{[65.257]}\end{array}$ & $\begin{array}{l}96.824^{*} \\
{[56.208]}\end{array}$ \\
\hline Observations & 130 & 84 & 84 & 84 & 84 & 160 & 121 & 121 & 121 & 121 \\
\hline R-squared & 11 & 9 & 9 & 9 & 9 & 10 & 9 & 9 & 9 & 9 \\
\hline Number of year & 0,796 & 0,73 & 0,725 & 0,735 & 0,756 & 0,42 & 0,509 & 0,519 & 0,525 & 0,979 \\
\hline St.Dev. of Dependent Variable & 22,37 & 22,37 & 22,37 & 22,37 & 22,37 & 95,08 & 95,08 & 95,08 & 95,08 & 95,08 \\
\hline
\end{tabular}

*** $p<0.01,{ }^{* *} p<0.05,{ }^{*} p<0.1$

TABLE 11: Subtitles channelled through television penetration and viewing - EU survey and adj. TOEFL

These tables report panel regressions in which the left hand side variables are the EU survey and adjusted TOEFL quality of English measurements. We include year fixed effects in all the regressions. The treatment effect regressions are carried out with a model including the dictatorship dummy and 1933 language size variables (no constant). In all models, robust standard errors are in parentheses. 


\begin{tabular}{|c|c|c|c|c|}
\hline & $\begin{array}{c}\text { Robustness to } \\
\text { technology } \\
\text { and economic } \\
\text { variables - EU } \\
\text { Survey } \\
\end{array}$ & $\begin{array}{c}\text { Treatment } \\
\text { Effects - EU } \\
\text { Survey } \\
\end{array}$ & $\begin{array}{c}\text { Robustness to } \\
\text { technology } \\
\text { and economic } \\
\text { variables - Adj. } \\
\text { TOEFL }\end{array}$ & $\begin{array}{c}\text { Treatment } \\
\text { Effects - Adj. } \\
\text { TOEFL }\end{array}$ \\
\hline Subtitles (Y/N) & $\begin{array}{c}19.278^{\star \star \star} \\
{[1.103]}\end{array}$ & & $\begin{array}{c}3,307 \\
{[1.748]}\end{array}$ & \\
\hline Subtitles (Y/N) - Instrumented & & $\begin{array}{c}24.378^{\star \star *} \\
{[2.667]}\end{array}$ & & $\begin{array}{c}12.770^{\star * *} \\
{[4.218]}\end{array}$ \\
\hline Similarity between local language and English & $\begin{array}{c}0.042^{\star \star *} \\
{[0.004]}\end{array}$ & $\begin{array}{c}0.043^{\star \star \star} \\
{[0.005]}\end{array}$ & $\begin{array}{c}0.041^{* * *} \\
{[0.009]}\end{array}$ & $\begin{array}{c}0.040^{\star \star *} \\
{[0.008]}\end{array}$ \\
\hline Years of English education at school & $\begin{array}{l}2.605^{\star *} \\
{[0.720]}\end{array}$ & $\begin{array}{c}2.134^{\star \star * *} \\
{[0.601]}\end{array}$ & $\begin{array}{c}0,426 \\
{[0.964]}\end{array}$ & $\begin{array}{l}-0,486 \\
{[0.902]}\end{array}$ \\
\hline GDP per capita, logs & $\begin{array}{c}0,38 \\
{[1.978]}\end{array}$ & $\begin{array}{c}5,741 \\
{[4.408]}\end{array}$ & $\begin{array}{c}4,967 \\
{[5.142]}\end{array}$ & $\begin{array}{c}13.679 * * \\
{[5.292]}\end{array}$ \\
\hline Country area in Square Kms2 / 1000 & $\begin{array}{l}-0,331 \\
{[7.981]}\end{array}$ & $\begin{array}{l}-0,644 \\
{[6.580]}\end{array}$ & $\begin{array}{c}-19.314^{* *} \\
{[7.571]}\end{array}$ & $\begin{array}{c}-19.872^{* *} \\
{[8.479]}\end{array}$ \\
\hline Trade to GDP & $\begin{array}{c}-0,641 \\
{[1.653]}\end{array}$ & $\begin{array}{l}-1,736 \\
{[3.042]}\end{array}$ & $\begin{array}{c}12.376^{\star \star \star} \\
{[2.495]}\end{array}$ & $\begin{array}{c}12.152^{\star \star \star} \\
{[4.342]}\end{array}$ \\
\hline$\%$ of people employed in service sector & $\begin{array}{c}41.869^{\star \star * *} \\
{[5.566]}\end{array}$ & $\begin{array}{c}13,992 \\
{[13.735]}\end{array}$ & $\begin{array}{l}-33.153^{\star \star} \\
{[11.199]}\end{array}$ & $\begin{array}{c}-70.869^{\star \star \star *} \\
{[15.435]}\end{array}$ \\
\hline$\%$ GDP from touristic activity & $\begin{array}{c}-0.954^{\star *} \\
{[0.322]}\end{array}$ & $\begin{array}{c}-1.241^{\star \star \star} \\
{[0.442]}\end{array}$ & $\begin{array}{c}-3.009^{\star \star \star *} \\
{[0.715]}\end{array}$ & $\begin{array}{c}-3.330^{\star \star \star *} \\
{[0.620]}\end{array}$ \\
\hline$\%$ workforce in $\mathrm{R} \% \mathrm{D}$ activities & $\begin{array}{c}0,023 \\
{[0.204]}\end{array}$ & $\begin{array}{l}-0,067 \\
{[0.351]}\end{array}$ & $\begin{array}{c}0,331 \\
{[0.195]}\end{array}$ & $\begin{array}{c}0,188 \\
{[0.641]}\end{array}$ \\
\hline Internet penetration & $\begin{array}{c}0,006 \\
{[0.011]}\end{array}$ & $\begin{array}{c}0,008 \\
{[0.010]}\end{array}$ & $\begin{array}{l}-0,007 \\
{[0.016]}\end{array}$ & $\begin{array}{l}-0,005 \\
{[0.014]}\end{array}$ \\
\hline$\%$ of exports that are hightech & $\begin{array}{c}1,482 \\
{[1.333]}\end{array}$ & $\begin{array}{c}1,995 \\
{[2.235]}\end{array}$ & $\begin{array}{c}13.057^{* *} \\
{[3.796]}\end{array}$ & $\begin{array}{c}13.654^{\star * \star} \\
{[2.880]}\end{array}$ \\
\hline Inverse Mills Ratio & & $\begin{array}{c}-8.435^{\star \star \star} \\
{[2.458]}\end{array}$ & & $\begin{array}{c}-13.108^{\star \star \star *} \\
{[3.714]}\end{array}$ \\
\hline Constant & $\begin{array}{c}-182.809 * * * \\
{[26.285]}\end{array}$ & $\begin{array}{c}-114.980^{\star *} \\
{[50.808]}\end{array}$ & $\begin{array}{c}201.685^{\star \star *} \\
{[24.608]}\end{array}$ & $\begin{array}{c}276.210 * \star \star \\
{[49.739]} \\
\end{array}$ \\
\hline Observations & 96 & 96 & 121 & 121 \\
\hline R-squared & 7 & 7 & 7 & 7 \\
\hline Number of year & 22,37 & 22,37 & 95,08 & 95,08 \\
\hline St.Dev. of Dependent Variable & 0,856 & 0,872 & 0,628 & 0,979 \\
\hline
\end{tabular}

Robust standard errors in brackets

*** $p<0.01,{ }^{* \star} p<0.05,{ }^{*} p<0.1$

\section{TABLE 12: Many more explanatory variables: EU survey and adjusted TOEFL}

This table reports panel regressions in which the left hand side variables are the EU survey and adjusted TOEFL quality of English measurements. We include year fixed effects in all the regressions. The treatment effect regressions are carried out with a model including the dicatatorship dummy and 1933 language size variables (no constant). GDP, trade, employment in service sector, touristic activity, R\&D, internet penetration and high-tech exports are all contemporary data obtained from the IMD World Competitiveness Yearbook. In all models, robust standard errors are in parentheses. 
OLS Model 1 - OLS Model 2 - OLS Model 3 - OLS Model 4 - OLS Model 1 - OLS Model 2 - OLS Model 3 - OLS Model 4

Percent of Movies Only Subtitled in 2006

$\%$ Of Subtitled Films $x$ Average Annual Cinema Attendance per Capita

Similarity between local language and English

Years of English education at schoo

PISA education quality assessment

Expenditure in public education per capita

Pupil to teacher ratio

Constant

.7.780.

$\begin{array}{llllll}-8.255^{\star \star \star} & -7.751^{\star \star} & -17.036^{\star \star \star} & -11.815^{\star \star \star} & 9.748^{\star \star \star} & 26.532^{\star \star \star *}\end{array}$

$\begin{array}{llllllll}{[2.277]} & {[2.969]} & {[3.479]} & {[3.512]} & {[2.285]} & {[4.926]} & {[6.038]} & {[5.872]}\end{array}$

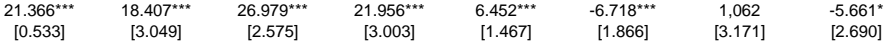

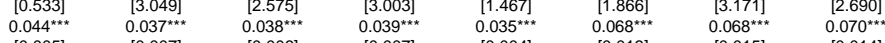

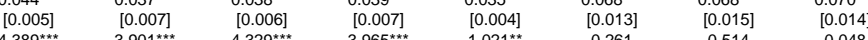

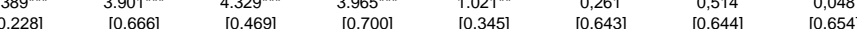

$\begin{array}{llllllll}0.110^{\star \star \star} & 0,098 & 0,075 & 0,087 & 0.254^{\star \star} & 0.490^{\star \star} & 0.467^{\star \star} & 0.482^{\star \star}\end{array}$

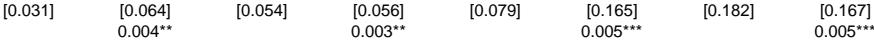

$\begin{array}{cccc}0.004^{\star \star} & 0.003^{\star \star} & 0.005^{\star \star \star} & 0.005^{\star \star} \\ 0.002] & {[0.001]} & {[0.001]} & {[0.001]}\end{array}$

Observations

Number of ye

Dev of Dependent Variable

Robust standard errors in brack

$p<0.01,{ }^{* *} p<0.05,{ }^{*} p<0.1$

This table reports panel regressions in which the left hand side variables are the EU survey and adjusted TOEFL quality of English measurements. We include year fixed effects

in all the regressions. The treatment effect regressions are carried out with a model including the dictatorship dummy and 1933 language size variables (no constant). In all

models, robust standard errors are in parentheses. 


\begin{tabular}{|c|c|c|c|c|c|c|c|c|c|c|}
\hline & $\begin{array}{l}\text { OLS - High- } \\
\text { Tech Exports }\end{array}$ & $\begin{array}{c}\text { Treatment } \\
\text { Effects - High- } \\
\text { Tech Exports }\end{array}$ & $\begin{array}{c}\text { OLS - } \\
\text { Students going } \\
\text { to US } \\
\end{array}$ & $\begin{array}{c}\text { Treatment } \\
\text { Effects - } \\
\text { Students going } \\
\text { to US } \\
\end{array}$ & $\begin{array}{c}\text { OLS - } \\
\text { Acquisitions of } \\
\text { US/UK Firms }\end{array}$ & $\begin{array}{l}\text { Treatment } \\
\text { Effects - } \\
\text { Acquisitions of } \\
\text { US/UK Firms }\end{array}$ & $\begin{array}{c}\text { OLS - Listings } \\
\text { in the US }\end{array}$ & $\begin{array}{c}\text { Treatment } \\
\text { Effects - } \\
\text { Listings in the } \\
\text { US } \\
\end{array}$ & $\begin{array}{c}\text { OLS - US } \\
\text { FDI }\end{array}$ & $\begin{array}{c}\text { Treatment } \\
\text { Effects - US } \\
\text { FDI } \\
\end{array}$ \\
\hline Subtitles $(\mathrm{Y} / \mathrm{N})$ & $\begin{array}{c}0.329 * \star \star \\
{[0.038]}\end{array}$ & & $\begin{array}{l}0.053^{\star *} \\
{[0.015]}\end{array}$ & & $\begin{array}{c}10.712^{\star \star \star} \\
{[1.282]}\end{array}$ & & $\begin{array}{c}2.673^{\star \star \star} \\
{[0.607]}\end{array}$ & & $\begin{array}{c}21.293^{\star \star \star} \\
{[4.807]}\end{array}$ & \\
\hline Subtitles $(\mathrm{Y} / \mathrm{N})$ - Instrumented & & $\begin{array}{l}0.465^{\star \star \star} \\
{[0.133]}\end{array}$ & & $\begin{array}{c}0.079^{\star \star \star} \\
{[0.020]}\end{array}$ & & $\begin{array}{c}13.955^{\star \star \star} \\
{[3.010]}\end{array}$ & & $\begin{array}{l}2.985^{\star} \\
{[1.599]}\end{array}$ & & $\begin{array}{l}21.175^{\star} \\
{[11.296]}\end{array}$ \\
\hline Similarity between local language and English & $\begin{array}{c}0.000^{\star \star \star} \\
{[0.000]}\end{array}$ & $\begin{array}{c}0 \\
{[0.000]}\end{array}$ & $\begin{array}{c}0.000^{\star \star \star} \\
{[0.000]}\end{array}$ & $\begin{array}{c}0.000^{\star \star \star} \\
{[0.000]}\end{array}$ & $\begin{array}{l}-0,001 \\
{[0.006]}\end{array}$ & $\begin{array}{l}-0,003 \\
{[0.008]}\end{array}$ & $\begin{array}{l}-0.003^{*} \\
{[0.002]}\end{array}$ & $\begin{array}{l}-0,003 \\
{[0.003]}\end{array}$ & $\begin{array}{c}-0.021^{\star \star} \\
{[0.008]}\end{array}$ & $\begin{array}{c}-0,02 \\
{[0.019]}\end{array}$ \\
\hline Years of English education at school & $\begin{array}{c}0,003 \\
{[0.022]}\end{array}$ & $\begin{array}{l}-0,011 \\
{[0.032]}\end{array}$ & $\begin{array}{l}0.011^{*} \\
{[0.005]}\end{array}$ & $\begin{array}{l}0.009^{*} \\
{[0.005]}\end{array}$ & $\begin{array}{l}-2,002 \\
{[1.200]}\end{array}$ & $\begin{array}{l}-2,307 \\
{[1.416]}\end{array}$ & $\begin{array}{c}0,038 \\
{[0.386]}\end{array}$ & $\begin{array}{c}0,008 \\
{[0.619]}\end{array}$ & $\begin{array}{c}12.197^{\star \star \star} \\
{[1.665]}\end{array}$ & $\begin{array}{c}12.266^{\star \star \star} \\
{[4.170]}\end{array}$ \\
\hline PISA education quality assessment & $\begin{array}{l}0.008^{\star \star} \\
{[0.003]}\end{array}$ & $\begin{array}{l}0.006^{\star \star} \\
{[0.003]}\end{array}$ & $\begin{array}{c}-0.001^{\star \star *} \\
{[0.000]}\end{array}$ & $\begin{array}{c}-0.001^{\star *} \\
{[0.001]}\end{array}$ & $\begin{array}{l}-0.088^{\star \star \star} \\
{[0.022]}\end{array}$ & $\begin{array}{c}-0.122^{\star *} \\
{[0.047]}\end{array}$ & $\begin{array}{c}-0.053^{\star \star \star} \\
{[0.005]}\end{array}$ & $\begin{array}{c}-0.056^{\star \star \star} \\
{[0.020]}\end{array}$ & $\begin{array}{c}-0.448^{\star \star \star} \\
{[0.106]}\end{array}$ & $\begin{array}{c}-0.459^{\star \star} \\
{[0.198]}\end{array}$ \\
\hline GDP per capita, logs & $\begin{array}{c}0.811^{\star \star \star} \\
{[0.130]}\end{array}$ & $\begin{array}{c}0.834^{\star \star \star *} \\
{[0.160]}\end{array}$ & $\begin{array}{c}-0.077^{\star \star \star} \\
{[0.013]}\end{array}$ & $\begin{array}{c}-0.074^{\star \star \star} \\
{[0.018]}\end{array}$ & $\begin{array}{c}21.019^{* \star *} \\
{[3.972]}\end{array}$ & $\begin{array}{c}21.502^{\star \star \star} \\
{[4.492]}\end{array}$ & $\begin{array}{c}9.272^{\star \star \star} \\
{[0.982]}\end{array}$ & $\begin{array}{c}9.319^{\star \star \star \star} \\
{[1.871]}\end{array}$ & $\begin{array}{c}31.166^{\star \star \star} \\
{[3.576]}\end{array}$ & $\begin{array}{c}30.942^{\star \star \star} \\
{[10.516]}\end{array}$ \\
\hline Country area in Square Kms2 / 1000000 & $\begin{array}{c}0,478 \\
{[0.328]}\end{array}$ & $\begin{array}{c}0,448 \\
{[0.300]}\end{array}$ & $\begin{array}{c}0.451^{\star \star \star} \\
{[0.045]}\end{array}$ & $\begin{array}{c}0.438^{\star \star \star} \\
{[0.079]}\end{array}$ & $\begin{array}{c}102.300^{\star \star \star} \\
{[15.907]}\end{array}$ & $\begin{array}{c}101.096^{\star \star \star} \\
{[15.461]}\end{array}$ & $\begin{array}{c}15.960^{* \star *} \\
{[3.776]}\end{array}$ & $\begin{array}{c}15.844^{\star \star \star} \\
{[5.760]}\end{array}$ & $\begin{array}{c}-36.923^{\star \star} \\
{[14.876]}\end{array}$ & $\begin{array}{l}-35,357 \\
{[33.490]}\end{array}$ \\
\hline Trade to GDP - logs & $\begin{array}{c}0,022 \\
{[0.137]}\end{array}$ & $\begin{array}{c}0,023 \\
{[0.230]}\end{array}$ & $\begin{array}{c}0,015 \\
{[0.015]}\end{array}$ & $\begin{array}{c}0,008 \\
{[0.027]}\end{array}$ & $\begin{array}{c}24.666^{\star \star *} \\
{[4.252]}\end{array}$ & $\begin{array}{c}24.373^{\star * *} \\
{[5.228]}\end{array}$ & $\begin{array}{l}5.044^{\star \star \star} \\
{[1.071]}\end{array}$ & $\begin{array}{l}5.016^{* *} \\
{[2.331]}\end{array}$ & $\begin{array}{c}39.349^{* \star *} \\
{[5.127]}\end{array}$ & $\begin{array}{l}40.083^{\star * \star} \\
{[12.567]}\end{array}$ \\
\hline GDP total - logs & $\begin{array}{c}0,029 \\
{[0.033]}\end{array}$ & $\begin{array}{c}0,023 \\
{[0.053]}\end{array}$ & $\begin{array}{c}-0.067^{\star \star \star} \\
{[0.005]}\end{array}$ & $\begin{array}{c}-0.068^{\star \star \star} \\
{[0.008]}\end{array}$ & $\begin{array}{c}0,006 \\
{[1.443]}\end{array}$ & $\begin{array}{l}-0,086 \\
{[2.181]}\end{array}$ & $\begin{array}{c}3.976^{\star \star *} \\
{[0.429]}\end{array}$ & $\begin{array}{c}3.967^{\star \star \star} \\
{[1.080]}\end{array}$ & $\begin{array}{c}34.147^{\star \star \star} \\
{[3.186]}\end{array}$ & $\begin{array}{c}34.079^{\star \star \star} \\
{[9.526]}\end{array}$ \\
\hline Inverse Mills Ratio & & $\begin{array}{l}-0.198^{\star \star} \\
{[0.087]}\end{array}$ & & $\begin{array}{l}-0.037^{*} \\
{[0.022]}\end{array}$ & & $\begin{array}{c}-4.493^{\star *} \\
{[1.785]}\end{array}$ & & $\begin{array}{l}-0,432 \\
{[0.690]}\end{array}$ & & $\begin{array}{l}2,839 \\
{[9.896]}\end{array}$ \\
\hline Intercept & $\begin{array}{c}-10.083^{\star \star \star} \\
{[2.136]}\end{array}$ & $\begin{array}{c}-9.351^{\star \star \star} \\
{[1.732]}\end{array}$ & $\begin{array}{c}1.338^{\star \star \star *} \\
{[0.052]}\end{array}$ & $\begin{array}{c}1.490^{\star \star \star} \\
{[0.335]} \\
\end{array}$ & $\begin{array}{c}-252.704^{\star * *} \\
{[38.268]} \\
\end{array}$ & $\begin{array}{c}-236.419^{\star \star \star} \\
{[42.319]}\end{array}$ & $\begin{array}{c}-105.448^{\star \star \star} \\
{[9.797]} \\
\end{array}$ & $\begin{array}{c}-103.881^{\star \star \star} \\
{[16.120]} \\
\end{array}$ & $\begin{array}{c}-522.739 \star \star \star \\
{[77.370]} \\
\end{array}$ & $\begin{array}{c}-518.593^{\star \star *} \\
{[108.625]} \\
\end{array}$ \\
\hline Observations & 115 & 115 & 114 & 114 & 150 & 150 & 150 & 150 & 125 & 125 \\
\hline $\begin{array}{l}\text { R-squared } \\
\text { Number of year }\end{array}$ & 8 & $\begin{array}{c}0,764 \\
8\end{array}$ & 7 & $\begin{array}{c}0,58 \\
7\end{array}$ & 10 & $\begin{array}{c}17,46 \\
10\end{array}$ & 10 & $\begin{array}{c}8,388 \\
10\end{array}$ & $\begin{array}{c}0,496 \\
8\end{array}$ & $\begin{array}{c}0,514 \\
8\end{array}$ \\
\hline St.Dev. of Dependent Variable & 0,65 & 0,668 & 0,585 & 0,622 & 0,542 & 0,571 & 0,551 & 0,56 & 46,02 & 46,02 \\
\hline
\end{tabular}

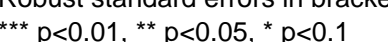

\section{Table 14: Consequences of subtitling}

This table reports panel regressions with three dependent variables: a. the country's high-tech exports (Source: IMD Competitiveness Yearbook); b. the ratio between the number of nationals of the country pursuing higher education in the US to total population (Source: Opendoors' Report of International Educational Exchange http://opendoors.iienetwork.org), and; c. the correlation the US and each country votes in the United Nations (Source: Erik A. Gartzke). GDP, trade, employment in service sector, touristic activity, R\&D, internet penetration and high-tech exports are all contemporary data obtained from the IMD World Competitiveness Yearbook. We include year fixed effects in all the regressions. The treatment effect regressions are carried out with a model including the dictatorship dummy and 1933 language size variables (no constant). In all models, robust standard errors are in parentheses. 